
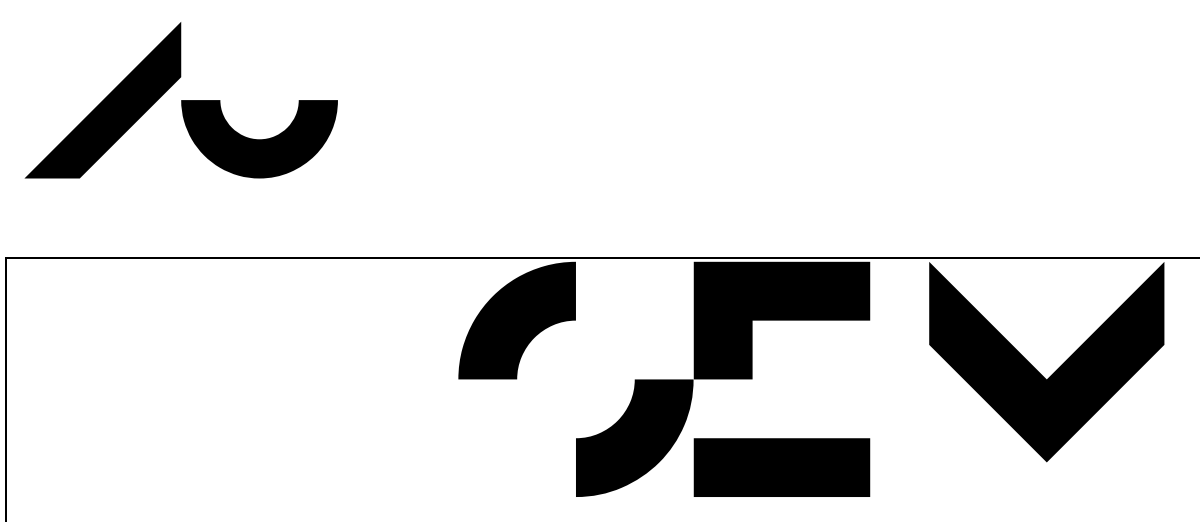

Economics Working Paper

2010-17

\title{
Weathering the financial storm: The importance of fundamentals and flexibility
}

Thorvardur Tjörvi Ólafsson and Thórarinn G. Pétursson

Bartholins Allé 10, Building 1322

DK-8000 Aarhus C - Denmark

Phone +4589421610

Mail: oekonomi@econ.au.dk

Web: www.econ.au.dk 


\title{
Weathering the financial storm: The importance of fundamentals and flexibility ${ }^{1}$
}

\author{
Thorvardur Tjörvi Ólafsson \\ Central Bank of Iceland and Aarhus University \\ Thórarinn G. Pétursson \\ Central Bank of Iceland
}

September 2010

\begin{abstract}
The recent global financial tsunami has had economic consequences that have not been witnessed since the Great Depression. But while some countries suffered a particularly large contraction in economic activity on top of a system-wide banking and currency collapse, others came off relatively lightly. In this paper, we attempt to explain this cross-country variation in post-crisis experience, using a wide variety of pre-crisis explanatory variables in a sample of 46 medium-to-high income countries. We find that domestic macroeconomic imbalances and vulnerabilities were crucial for determining the incidence and severity of the crisis. In particular, we find that the pre-crisis rate of inflation captures factors which are important in explaining the post-crisis experience. Our results also suggest an important role for financial factors. In particular, we find that large banking systems tended to be associated with a deeper and more protracted consumption contraction and a higher risk of a systemic banking or currency crisis. Our results suggest that greater exchange rate flexibility coincided with a smaller and shorter contraction, but at the same time increased the risk of a banking and currency crisis. Countries with exchange rate pegs outside EMU were hit particularly hard, while inflation targeting seemed to mitigate the crisis. Finally, we find some evidence suggesting a role for international real linkages and institutional factors. Our key results are robust to various alterations in the empirical setup and we are able to explain a significant share of the cross-country variation in the depth and duration of the crisis and provide quite sharp predictions of the incidence of banking and currency crises. This suggests that country-specific initial conditions played an important role in determining the economic impact of the crisis and, in particular, that countries with sound fundamentals and flexible economic frameworks were better able to weather the financial storm.
\end{abstract}

Keywords: $\quad$ Global financial crisis, real economy impact, banking and currency crisis, initial conditions, cross-country analysis

JEL classification:

F30, F31, F32, F41, G01

\footnotetext{
${ }^{1}$ This paper was prepared for the conference "The Euro Area and the Financial Crisis", at the National Bank of Slovakia, Bratislava, 6-8 September 2010. We are grateful to the conference participants, and especially the discussant on the paper, Atanas Christev, for helpful comments and suggestions. We are also grateful to David Cobham for fruitful discussions on the project and to Francis Breedon, Már Gudmundsson, Andrew Rose and participants at a seminar in the Central Bank of Iceland for helpful comments on earlier versions of the paper. Finally, we would like to thank Luc Laeven and Fabio Valencia who kindly shared an update of their banking crises database and Helga Gudmundsdóttir for helping with data. All remaining errors and omissions are ours. The views expressed do not necessarily reflect those of the Central Bank of Iceland. E-mail addresses: tolafsson@econ.au.dk (Ólafsson) and thgp@cb.is (Pétursson; corresponding author).
} 


\section{Introduction}

The recent global financial tsunami has had economic consequences that have not been witnessed since the Great Depression. But while some countries suffered a particularly large contraction in economic activity on top of a system-wide banking and currency collapse, others came off relatively lightly. This paper aims to explain this difference in cross-country experience by means of a non-structural econometric analysis using a variety of potential precrisis explanatory variables in a cross-section of 46 medium-to-high income countries. The severity of the macroeconomic impact is measured in terms of depth and duration of the contraction in both output and consumption. Potential pre-crisis explanatory variables are chosen to reflect propagation channels for the global crisis typically mentioned in the literature, i.e. a financial channel, a trade channel, a macro channel and an institutional channel, although we offer some new variables that have not been included in such analyses before as far as we know. As another contribution to the analysis of the current crisis, we also use cross-country probit regressions to identify the main determinants of the probability of a domestic systemic banking or currency crises during the current crisis.

Our results suggest that the macro channel played a prominent role, as domestic macroeconomic imbalances and vulnerabilities are found crucial for determining the incidence and severity of the crisis. An especially important pre-crisis macroeconomic indicator, which seems to capture factors that are important in explaining the extent of the crisis along many different dimensions, is the rate of inflation in the run up to the crisis. We also find evidence suggesting the importance of financial factors. In particular, we find that large banking systems tended to be associated with a deeper and more protracted consumption contraction and a higher risk of a systemic banking or currency crisis. Our results suggest that greater exchange rate flexibility coincided with a smaller and shorter contraction, but at the same time increased the risk of a banking and currency crisis. We also find that countries with exchange rate pegs outside the European Monetary Union (EMU) were hit particularly hard, while inflation targeting seemed to mitigate the crisis. Finally, we find some evidence suggesting a role for international real linkages and institutional factors.

Several recent papers attempt to explain the cross-country variation in the impact of the global crisis. For example, the findings in Berkmen et al. (2009) suggest that private sector leverage, credit growth, exchange rate flexibility, trade composition, and the fiscal position are important in explaining the cross-country variation in output growth forecast revisions. Lane and Milesi-Ferretti (2010) show that current account deficits, credit and output growth rates, and exposure to trade and production of traded goods are all important predictors for the impact of the crisis on post-crisis output and domestic demand (including consumption) growth rates. Other papers are more sceptical about the importance of initial conditions. Using output growth, stock price and exchange rate changes and revisions to country's credit ratings as crisis indicators, Rose and Spiegel (2009a, b) find that initial conditions have limited predictive power. Only pre-crisis asset price changes and current account deficits are found to be robust crisis predictors, while they find weaker evidence for a role of pre-crisis credit growth. Claessens et al. (2010) are also somewhat sceptical concerning the importance of initial conditions, although they find that credit growth, 
mortgage debt, asset price appreciation, current account deficits and trade openness can predict the severity of the output contraction and the post-crisis developments of a financial stress index.

Our results, however, give us reason to be more optimistic on the predictive power of initial conditions in the current crisis, both in terms of explaining a significant share of the cross-country variation in the depth and duration of the crisis and in providing quite sharp predictions of the incidence of banking and currency crises. This therefore suggests that country-specific initial conditions played an important role in determining the economic impact of the crisis and, in particular, that countries with sound fundamentals and flexible economic frameworks were better able to weather the financial storm. We find that these results are robust to various alterations in the empirical setup.

The remainder of the paper is organised as follows. Section 2 discusses the country sample, our crisis measures and the potential explanatory variables used in the analysis. Section 3 presents the empirical results, both with regard to the real economy effects of the crisis and the probability of a banking and currency crisis. Results from some sensitivity analyses are also reported. The section ends with an interpretation of the key results from the paper. Section 4 concludes.

\section{The data}

\subsection{The country sample}

This section describes the country sample analysed in this paper. Since the incidence of the crisis and occurrences of domestic banking and currency crises was mainly notable in higherincome countries, the focus is on countries in the upper half of the income spectrum. Thus, the aim is to include countries of similar income levels and size as OECD member countries. Hence, countries with PPP adjusted per capita GDP lower than the poorest OECD member country (Turkey) and PPP adjusted GDP level lower than the smallest OECD member country (Iceland) are excluded. ${ }^{2}$ This gives a sample of 64 countries in total from the 227 countries recorded in the CIA World Factbook for the period 2006-2008. After eliminating countries with missing data, we are left with 46 countries, i.e. all the current 33 OECD member countries, plus Bulgaria, Croatia, Cyprus, Estonia, Hong Kong, Latvia, Lithuania, Malta, Romania, Russia, South Africa, Taiwan and Thailand.

Thus, the analysis includes all the 27 EU member countries, 6 other European countries and 13 countries outside of Europe. There are 27 industrial countries and 19 emerging market economies, of which 12 are in Central and Eastern Europe. Finally, the analysis includes 7 very small open economies, i.e. countries with populations below 2.5 million.

The sample also includes countries with a wide array of monetary policy frameworks. Thus, there are the 16 EMU countries, 4 countries pegging their currency to the euro within

\footnotetext{
${ }^{2}$ There is, however, one exception: Malta is included although its GDP level falls just short of Iceland's level, in order to add one observation of a very small, open economy.
} 
the ERM2 framework and 4 other unilateral exchange rate pegs. There are also 22 countries with a floating exchange rate, of which 19 follow an explicit inflation targeting (IT) regime. ${ }^{3}$ The analysis therefore includes a country sample with a wide range of monetary frameworks. Table 1 gives an overview of the sample.

\subsection{Crisis indicators}

There is no single, optimal way to measure economic losses due to financial crises and the results from this paper and the others quoted in the Introduction clearly show the need to look at many different crisis indicators. Various measures have therefore been put forward in the literature. Some focus on the fiscal costs of crises (e.g. Hoelscher et al., 2003), which captures the transfer of income due to crisis resolution policies rather than the extent of economic costs of the crisis. While most papers focus on various measures of output losses, this paper also focuses on consumption losses, which we think is important as it is clear that a special feature of this crisis is the unusually prominent role played by the highly indebted household sector in propagating and amplifying the financial shock, with an exceptionally large consumption contraction occurring in many countries. We also focus on the duration of the crisis with the aim to analyse whether the same factors explain the depth and duration of the crisis or whether different factors play a role in explaining the cross-country variation in the speed of recovery.

A common approach to measure the impact of crises on activity is to construct a counterfactual path in the absence of a crisis and measure the loss as the actual deviation from the constructed trend (see e.g. IMF, 1998, Bordo et al., 2001, and Laeven and Valencia, 2008). This approach may overstate both the depth and the duration of the economic impact for countries were the run-up to the crisis is characterised by booms that make activity levels along the constructed trend unsustainable and therefore unattainable even in the absence of a crisis. Furthermore, countries are often heading for recessions before the crisis erupts without an unsustainable boom taking place and in those cases, comparisons of actual activity levels with simple trends may exaggerate the degree of losses due to the crisis (see Hoggarth et al., 2002).

Instead of constructing a counterfactual path for output or consumption in the absence of crisis, we therefore attempt to measure the depth of output (consumption) contraction as the log-difference of seasonally adjusted GDP (consumption) level between peak in the period from 2007Q1 to 2008Q4 and the level in 2009Q4 (our final data observation). ${ }^{4}$ Our approach has the advantage of avoiding the need to construct a counterfactual path for GDP or consumption in absence of the crisis. Possible disadvantages are that the peak level in the run up to the crisis can in some cases represent an unsustainable level with an adjustment being unavoidable with or without a financial crisis taking place. Hence, our measure may overstate

\footnotetext{
${ }^{3}$ Information on monetary regimes is based on the latest IMF de facto classification of exchange rate regimes and monetary policy frameworks from 23 February 2009 (using data from 31 April 2008), but updating the framework in Slovakia to reflect its EMU membership from January 2009.

${ }^{4}$ Other measures were also considered, for example the difference between the 2007Q1-2008Q4 peak and the trough in 2008Q4-2009Q4 as well as the difference of the level in 2008Q3 and trough in 2008Q4-2009Q4. The results were very similar (with correlation between the measures all above 0.9 ).
} 
the economic loss due to the crisis in such cases but on the other hand, we are not extrapolating the growth level in the run up to the crisis which is likely to lead to an even further overstatement. In addition, the analysis ends in 2009Q4 which means that the full impact of the crisis may yet to be fully realised in some of the countries included. Our approach is similar to Cecchetti et al. (2009), who measure the depth of contractions following crises as the peak to trough decline in GDP where the peak is the highest GDP level within one year either side of the crisis date.

Duration of output (consumption) contractions is measured as the number of quarters with negative quarter-on-quarter growth in seasonally adjusted GDP (consumption) from 2008Q3 to 2009Q4. The starting point is chosen to capture the effects of the global crisis once it entered panic mode in September 2008 so as to avoid capturing normal business cycle adjustments unrelated to the crisis. Of course, it can be argued that tighter financial conditions due to the emerging global crisis from mid-2007 played a part in reinforcing the downturn in activity and bringing some advanced economies into recession at an earlier stage but we choose to focus our duration analysis on the impact of the crisis once it entered panic mode in late $2008 .^{5}$

We also want to analyse the cross-country variation in the probability of a banking and currency crisis. The incidence of a systemic banking crises is based on an updated version of the database in Laeven and Valencia (2008), generously provided by the authors, in addition to our own elaboration. They categorise 10 countries from our country sample to have experienced a systemic banking crisis during the global crisis: Austria, Belgium, Denmark, Germany, Iceland, Ireland, Luxemburg, the Netherlands, the UK and the US. We add Latvia, Russia and Switzerland (which Laeven and Valencia had as borderline cases at the time of our correspondence) to the list based on significant stress in the banking sectors of these countries and the extent of policy interventions. Hence, there are 13 incidences of systemic banking crises in our country sample.

The definition of currency crises also follows Laeven and Valancia's (2008) using BIS's nominal effective exchange rate indices (see also Frankel and Rose, 1996). We categorise a country as having experienced a currency crisis if the annual average of the nominal effective exchange rate depreciated by $30 \%$ or more in $2008-2009$ and if this depreciation is also at least a 10 percentage points increase in the rate of depreciation compared to the two year period before. Given this definition, only two countries experienced a currency crisis between 2008 and 2009, Iceland and Korea, and therefore only Iceland experienced a twin crisis (see the Appendix for more detail). ${ }^{6}$

\footnotetext{
${ }^{5} \mathrm{We}$ also considered other measures of duration with similar results. Two examples were the number of quarters below peak and the number of quarters before two consecutive quarters of positive quarter-on-quarter growth, respectively. The correlation between these two measures, on the one hand, and the measure chosen on the other, is very high (above 0.8 ) for both output and consumption contractions.

${ }^{6}$ The Icelandic króna depreciated by roughly $48 \%$ in total between 2007 and 2009, while the Korean Won fell by $30 \%$. Expanding the criteria to other countries with large depreciations in both 2008 and 2009, would next include Pound Sterling (22\% depreciation between 2007 and 2009) and the Romanian lei (19\% depreciation between 2007 and 2009). We decided however to stick to the stricter criteria as we find no supporting evidence suggesting that a currency crisis occurred in the UK during 2008-9.
} 


\subsection{Potential pre-crisis explanatory variables}

We use a range of variables to analyse which factors played a role in determining the depth and duration of the contraction in activity, on one hand, and the probability of banking and currency crisis, on the other. In a broad sense, they can be categorised into four general channels from which the crisis was transmitted throughout the world economy: a financial channel (reflecting factors such as financial structure, development and cross-country linkages), a trade channel (reflecting factors such as trade penetration, trade structure and business cycle synchronisation), a macro channel (reflecting macroeconomic volatility and imbalances), and a channel reflecting institutional factors. To avoid possible endogeneity problems, all of our explanatory variables are measured at pre-crisis values, with most dated in 2006 or 2007 or values obtained from time series data with a cut-off point in 2007 or earlier. These variables and their motivation are further discussed in the following. A detailed list of variable definitions and sources can be found in the Appendix.

\section{Economic structure}

The first set of explanatory variables includes two measures of economic size and development, i.e. the PPP-adjusted US dollar value of GDP and the corresponding per capita measure of GDP. The motivation of including these measures is to capture and control for the effects of size and development on the economic impact of the crisis and the probability of a banking and currency crisis.

The global crisis originated in the advanced economies and spread throughout the globe (see, for example, Claessens et al., 2010), and the evidence in Lane and Milesi-Ferretti (2010) suggests that the advanced economies were hit hardest by the crisis. This is different from many previous crises in the last few decades and reflects the advanced-economy nature of the current crisis. In fact, the experience from previous crises with regard to difference in output contraction in developed countries compared to their less developed counterparts is ambiguous, although large consumption contractions are more frequently observed in the latter group. The frequency of banking and currency crises seems however remarkably similar in developed and developing countries (see Reinhart and Rogoff, 2009, Hoggarth et al., 2002, Dell'Ariccia et al., 2008, and Barro and Ursúa, 2008). To capture these effects, we include per capita GDP. But including per capita income can also serve as a proxy for other economic and institutional factors that are probably positively correlated with greater ability to absorb and respond to adverse shocks. However, as noted by Rose and Spiegel (2009a), this greater perceived ability to respond to crises may lead to greater moral hazard problems, thus leaving richer countries just as vulnerable as their less developed counterparts.

The crisis has also generally been observed as a crisis were smaller countries, which make up a significant share of the country sample used here, have taken a particularly big hit (see the discussion in Rose and Spiegel, 2009a). Many of these small countries had experienced large build-up of imbalances and were also heavily exposed to the collapse of international trade and activity and tightening financial conditions that followed the financial crisis than larger economies. The smaller countries are probably also less able to absorb shocks than the larger ones. Including economic size is meant to capture these effects. 


\section{Financial structure and development}

As a second set of explanatory variables we include three different measures of financial structure and development. It is often argued that the level of financial sophistication reached during the years prior to the crisis, if not triggering the crisis, at least served to exacerbate it and propagate it around different financial markets and around the world through rising moral hazard problems, opaque and complicated financial instruments and the inability of financial regulators to effectively regulate the financial system. ${ }^{7}$ At the same time, deeper financial markets can be more able to absorb shocks and support the recovery from a crisis than thin markets with few financial instruments for hedging risk that may even disappear completely during crisis periods. The question of sign of these effects is therefore ultimately an empirical one.

The first variable we include measures financial deepening, using the ratio of broad money (M2) to GDP, a standard measure of development of financial markets and hence their ability to absorb and diversify risk. A higher degree of financial development could be expected to be negatively related to the size and duration of the contraction following the crisis. However, if this measure merely reflects the ability of domestic agents to increase their leverage and hence contribute to greater imbalances through asset price bubbles and unsustainable balance sheets expansion, it could instead indicate greater vulnerability to the crisis and have a positive relation to the size of the crisis' economic impact (cf. Dell'Ariccia et al., 2008, and Claessens et al., 2010).

The second variable measures the size of the domestic banking system as the ratio of total assets of the five largest banks to GDP. ${ }^{8}$ Large banking systems, with significant crossborder operations, may have served to exacerbate the transmission of the global crisis to the domestic economy (cf. Davis, 2008, and Claessens et al., 2010). They may also stretch the ability of domestic regulators to deal with such large and complex banking systems and the fiscal resources to support the system in times of need. ${ }^{9}$ They may also exacerbate the risk of regulative capture and the moral hazard problem related to the too-big-to-fail problem (cf. Demirguc-Kunt and Serven, 2009). Large banking systems with significant cross-border operations are also more vulnerable to a liquidity crisis, such as happened in the current crisis as the host country's lender-of-last resort abilities were in many cases restricted to the domestic currency of which only a small share of the banking system's assets and liabilities

\footnotetext{
${ }^{7}$ See, for example, the discussions in Rose and Spiegel (2009a) and the references therein.

${ }^{8}$ The results were robust to whether the three, four or five of the largest banks were used. We also tried using the largest domestically-owned banks listed in The Banker's Top 1000 World Bank list (although the coverage was not as comprehensive as the one we use), which might be more closely related to the probability of banking crisis than our measure, e.g. due to sovereign's contingent liabilities from supporting domestically-owned banks. However, the effects on our results were only minor. An alternative source would be the BIS's consolidated banking statistics for national banking systems but that covers only half of our country sample.

${ }^{9}$ Due to data limitations, we could not include detailed banking system data often mentioned in the discussion as having played a role in the current crisis, such as such as banking interconnectedness, cross-currency funding needs, and currency and maturity mismatches present in banking systems in the run up to the crisis. Another potentially important pre-crisis condition missing due to data limitations is data on interbank turnover, which could capture the serious market disruption that occurred in many countries and differentiate more clearly between different types of market structures that could have played a role in the propagation of the crisis.
} 
are denominated in (cf. Buiter and Sibert, 2008). Finally, a relatively large banking system can also reflect excessive domestic credit expansion which is likely to contribute to the size of the crisis' economic impact. The size of the banking system may also at the same time reflect the type of financial intermediation prevalent in the economy, i.e. whether bank lending or financial markets are most important for financial intermediation. A higher share of direct lending via credit markets may have been beneficial in the current crisis, for example if bank lending has been more affected than direct financing through the bond market.

Finally, as a third measure of financial development and structure, we use the ratio of stock market capitalisation to GDP. The stock market plays an important role in corporate funding in many economies and is often considered a vital indicator for a country's economic strength. ${ }^{10}$ Deep stock markets could be expected to provide an important mean for channelling funds to medium-sized and large firms with productive investment opportunities in a time of crisis and cushion against bank credit retrenchment, in addition to allowing banks to raise new equity in an environment of rapidly deteriorating asset values. However, this is not necessarily true in a severe crisis. Declining equity prices can undermine corporate net worth, collateral values and limit their access to credit even further, decelerating investment and activity. Issuance of bank stock can also be problematic in practice in an environment of extensive counterparty risk and asset value uncertainty. Furthermore, high stock market capitalisation can also reflect asset price bubbles and therefore be an indicator of vulnerability rather than financial development (cf. Rose and Spiegel, 2009a, b).

\section{International real linkages}

The financial crisis literature stresses the importance of international trade as a key channel of crisis contagion. With the global recession causing a sharp decline in global demand, the spillover effects can be expected to be greater in countries with closer ties to the global economy (cf. Rose and Spiegel, 2009b, and Levchenko et al., 2009). We therefore add as a third set of explanatory variables five different measures of macroeconomic exposure to external shocks through trade linkages.

To capture the effects of trade intensity, we use a standard measure of trade openness, i.e. the ratio of the sum of exports and imports of goods and services to GDP. As a complimentary measure of these global real linkages, we also add a proxy for the link between the domestic and global business cycles, i.e. the contemporaneous correlation between the domestic and global output gaps, measured as de-trended output (using a Hodrick-Prescott filter). ${ }^{11}$ Furthermore, with the global recession dominated by a large contraction in demand for manufacturing goods across the globe, it can also be argued that

\footnotetext{
${ }^{10}$ Understandably, stock markets play a large role in market-based economies and therefore also reflect the type of financial system in each country.

${ }^{11}$ Note that the simple correlation may overstate the co-movement for the large economies as they represent a significant part of the world output measure used here. To adjust for this, an alternative measure of world output excluding the largest economies individually was constructed (using constant US dollar price data obtained from Eurostat). Hence, to calculate the US correlation, US output was compared to world output excluding the US. A similar adjustment was made for the other five large economies (France, Germany, Italy, Japan, and the UK). This led to a significant reduction in the correlation for Japan, the UK and the US, but had no effect on the measured correlation for the other three countries.
} 
countries whose exports are dominated by manufacturing goods were hit particularly hard by the crisis. To capture this compositional aspect, we therefore also include as a third variable the share of manufacturing goods in total merchandise exports.

The final two variables capture the possible effects of trade patterns on the transmission of the global shock to the domestic economy through the trade channel. Countries that export only a narrow range of goods or have trade concentrated on few markets may be expected to be more vulnerable to the global crisis than countries who export a broad menu of goods to many markets. These effects are captured by two indices on trade diversification and trade concentration. The first index measures how a country's exports differ from that of the average country. A country with a narrow export base will have a high value of this index. The second index measures the degree of market concentration in trade. A country with exports concentrated on few markets will have a high value of this index.

\section{International financial linkages}

The fourth set of explanatory variables proxies the extent of financial linkages with the global economy. These variables are included to capture the extent of countries' linkages with the international financial system as the crisis rapidly spread from the main financial centres to other countries across the globe (cf. Davis, 2008, and Rose and Spiegel, 2009b). It can be expected that closer financial links enhanced the spill-over of the financial shock to domestic financial systems. But at the same time, it can also be argued that stronger ties to the global financial system can facilitate a more rapid recovery from the crisis through greater access to global finance once the crisis hit.

To capture the extent of financial exposure to the global economy we use a general measure of financial openness, given as the ratio of the sum of foreign assets and liabilities to GDP, which is commonly used in the literature, cf. Kose et al. (2009). A high ratio implies stronger financial links with the international economy and therefore greater exposure to disruptions in credit markets and international asset price reversals. ${ }^{12}$ But as pointed out by Lane and Milesi-Ferretti (2010), a high ratio also reflects a more internationally diversified asset portfolio and can therefore also reflect some valuable diversification in the event of instability in the domestic financial system. The question whether a large international balance sheet is associated with a greater or lesser exposure to the global crisis is therefore ultimately an empirical one.

Closely related is a measure of the extent of capital inflows, given as the ratio of foreign direct investment (FDI) inflows to GDP. The reversibility of capital flows and the risk of sudden stop crises is a recurrent theme in the literature and the idea behind this variable is to capture the vulnerability of countries' risk to reversal due to the global crisis which could increase the economic impact. We follow Forbes and Chinn (2004) and use FDI inflows as a measure of vulnerability to capital inflows reversal. FDI inflows may, however, not be the type of inflows most sensitive to such abrupt reversals but data limitations prevented us from using other measures such as foreign portfolio flows and foreign bank loans, which may be

\footnotetext{
${ }^{12}$ This ignores the importance of the structure of external assets and liabilities, e.g. the share of equity versus short-term debt in liabilities and the degree of risk in foreign asset holdings.
} 
more important drivers of capital flow reversals (see e.g. Tong and Wei, 2009). This view has though been questioned, with Dooley et al. (1994) finding a high level of FDI to be associated with high variability in capital flows and Frankel and Rose (1996) finding currency crashes to be related to episodes where FDI inflows dry up.

The final financial linkages variable is meant to capture the possible positive effects of global financial ties through a 'global security net' and is given as an indicator variable for access to the US Federal Reserve extraordinary US dollar liquidity swap facilities in the autumn of 2008. The Fed provided US dollar liquidity to a selection of central banks to ease pressure that occurred in US dollar short-term wholesale funding markets (McGuire and von Peter, 2009, and Allen and Moessner, 2010). ${ }^{13}$ Thus, the indicator variable takes the value of one if the domestic central bank had access to this liquidity program in the autumn of 2008 and zero otherwise. ${ }^{14}$

\section{Underlying economic volatility}

The fifth set of variables includes three measures of underlying economic volatility. In general, greater economic volatility can reflect frequent or large shocks, or poor success in dealing with shocks, e.g. due to weak institutions and lack of credibility. Greater underlying volatility could therefore be expected to make countries more vulnerable to the global crisis. But greater volatility in some macroeconomic variables can also capture greater flexibility which can foster a swift adjustment to shocks and support a more rapid recovery.

To capture these different dimensions of the link between crisis vulnerability and economic volatility, we first include a variable measuring business cycle volatility using the standard deviation of the output gap (using Hodrick-Prescott de-trended output) for quarterly data over the period from 1985 to 2007.

The second variable is the volatility of the nominal exchange rate, measured as the standard deviation of quarterly nominal effective exchange rates in the period from 1994 to 2007. A more volatile exchange rate can reflect a number of factors, e.g. underlying instability in the economy, high and volatile inflation and monetary policy's lack of credibility and transparency (e.g. Kuttner and Posen, 2000). But a more volatile exchange rate can also reflect greater exchange rate flexibility that can help mitigate economic shocks such as the recent global crisis through improved competitiveness of the domestic economy due to depreciation of the domestic currency. ${ }^{15}$

\footnotetext{
${ }^{13}$ Swap lines were set up with the European Central Bank and Swiss National Bank in December 2007. These lines were expanded considerably following Lehman Brother's collapse and similar swap lines were set up with the central banks of Japan, UK, Canada, Australia, Sweden, Norway, Denmark, New Zealand, Brazil, Mexico, Korea and Singapore. These facilities were terminated in early 2010 but some were reintroduced in May 2010 when funding pressures emerged again.

${ }^{14}$ The use of this indicator variable in our analysis may be problematic in the sense that the introduction of swap lines between central banks was part of the crisis response of monetary authorities. Any effects of this variable can therefore reflect a reverse causality instead of being a truly exogenous regressor.

${ }^{15}$ This shock-absorber role of a flexible exchange rate can be limited in practice however if currency mismatches are widespread as non-financial private sector or public sector balance sheets will be dealt a heavy blow by the depreciation, causing widespread repayment problems and write-downs of banks' assets. Data limitations prevent us from including these currency mismatches in the analysis.
} 
But not all currency movements serve to facilitate economic adjustment. As a final variable capturing underlying economic volatility, we therefore also add a measure of the non-fundamental part of exchange rate volatility. This measure is obtained from Pétursson (2010), which uses the standard monetary model of exchange rate determination to estimate the lower bound of the variance of a time-varying exchange rate risk premium within a rational-expectations signal extraction approach. The idea behind including this variable is that the more volatile the exchange rate risk premium is, the more vulnerable the economy is to the financial crisis.

\section{Economic imbalances and vulnerabilities}

The sixth set of initial conditions includes variables capturing macroeconomic conditions just before the crisis hit. The idea is that the larger the macroeconomic imbalances, the more vulnerable the economy is to adverse changes in financial and economic conditions. This is a well known characteristic of financial crises. Barajas et al. (2009) show for example that large macroeconomic imbalances tend to increase the probability of a crisis. They also find that the larger the imbalances, the longer the contraction following the crisis tends to be.

As a first measure of macroeconomic imbalances, we include the rate of inflation in 2007. Inflation control is likely to reflect the quality of policy institutions and the extent of demand pressures within each country, both of which can be expected to influence how vulnerable countries are to a global financial crisis and the possibility for policy makers to use monetary stimulus measures to cushion against adverse shocks. Thus, we expect countries with low inflation and better anchored inflation expectations to have greater scope to ease monetary policy more aggressively and be more effective in transforming lower policy rates into lower medium and long-term real rates than countries that were also dealing with inflationary problems by the time the crisis hit.

The second variable we include to capture macroeconomic imbalances is the current account balance as a share of GDP. Countries running current account deficits are more reliant on foreign financing and are therefore more exposed to a sudden stop of capital inflows, which is a frequent characteristic of financial crises (cf. Claessens et al., 2009). The ensuing balance of payment adjustment usually takes the form of rapidly declining domestic demand and currency depreciation. Larger deficits are likely to require larger adjustments in domestic demand and the exchange rate which can, if large enough, lead to a currency and banking crises through the depreciation's effect on domestic balance sheets (cf. Fratzscher, 2009).

Third, we include a variable capturing financial leverage of domestic balance sheets. In general terms, leverage refers to the degree to which assets are funded by debt and is therefore a useful indicator of balance sheet vulnerabilities. Excessive increase in leverage is also typically related to credit and asset price bubbles. At the time the bubbles burst and the crisis hits, private sector balance sheets are therefore particularly exposed to collapsing asset prices and refinancing risks and households and firms need to rapidly unwind their balance sheets which further exacerbates the slowdown of economic activity (see, for example, Rose and Spiegel, 2009a, b, and Claessens et al., 2010). Various leverage measures have been used 
in the literature, such as the debt-to-equity ratio and the debt-to-assets ratio. However, due to data limitations we follow Berkmen et al. (2009) and measure leverage with the ratio of domestic credit to domestic deposits. This compares total credit to a relatively liquid and limited form of assets but can nevertheless be expected to reflect the degree of balance sheet vulnerability and therefore how fragile countries are to tighter financial conditions and declining asset prices brought upon by the global crisis.

Fourth, we include two variables capturing the underlying vulnerability of the fiscal authority, i.e. fiscal balances and government debt (both measured as a ratio to GDP). These two variables should capture both the ability of the fiscal authority to respond to the crisis through a fiscal stimulus and the transmission of the crisis through the risk premium on government debt with possible repercussions on funding and debt sustainability. Higher debt levels and larger deficits are therefore expected to make countries more vulnerable to the crisis and limit their ability to mitigate its real effects. If debt sustainability is questioned due to high debt levels or large refinancing needs and causes considerable increase in risk premia, the government may have to introduce strict fiscal austerity measures that will further increase the contraction in domestic demand in the short run.

The final measure introduced to capture macroeconomic imbalances and vulnerabilities is central bank foreign reserves as a ratio to GDP. Low levels of reserves prior to the crisis may suggest limited capability of the monetary authority to support the domestic currency in a situation where the currency comes under pressure, as often occurs in times of financial stress. Limited reserves also reflect restricted ability to provide foreign currency liquidity support to the domestic banking system in times of financial panic as occurred during the US dollar liquidity shortage as previously discussed. Thus, countries with relatively low reserves can be expected to be hit harder by the crisis as their local currency and banking system come under more strain (cf. Fratzscher, 2009, and Obstfeld et al., 2009). ${ }^{16}$

\section{Institutional factors}

One can expect countries with stronger institutions to be better able to cope with crisis situations and in general to deliver a more stable macroeconomic environment (cf. Acemoglu et al., 2003), which may also make countries less vulnerable to the crisis as discussed above. The seventh set of initial conditions therefore includes ten variables capturing different institutional aspects.

First, we include four different measures of institutional quality: two separate proxies of governance quality from the World Bank, i.e. one measure of government efficiency and another of regulatory quality; a proxy for the quality of the legal system from the Fraser Institute's Economic Freedom of the World Index; and an index of central bank independence from Fry et al. (2000). We expect countries with a stronger governance structure and a sounder legal system to be more able to reduce the probability of imbalances building up, e.g.

\footnotetext{
16 The size of foreign reserves was to a certain extent made less important for countries with access to international swap lines. Of the main international centres, the euro area, the UK, Switzerland and Australia would have depleted a substantial fraction of their foreign currency reserves if they would have had to provide foreign currency liquidity out of their reserves without the use of central bank swap lines according to Allen and Moessner (2010).
} 
through reducing the risk of regulative capture. Greater central bank autonomy can also be argued to reduce the risk of crises by better insulating monetary policy from political pressures and therefore reducing the time-inconsistency problem and supporting firmer anchoring of inflation expectations.

Second, we include four measures of flexibility of markets, based on the Fraser Institute's Economic Freedom of the World Index: indices of regulatory burden in credit and labour markets, respectively, a measure of regulatory burden in overall business transactions, and a summary index of overall economic freedom (the EFW-index). Here, the idea is that greater flexibility and less regulatory burden may help economies recover faster from a crisis. But at the same time, it is often argued that one of the key drivers in the current crisis was 'too much' freedom and lax supervision of private sector behaviour. The possible effects of these institutional features are therefore not necessarily clear a priori.

Finally, we include two indicator variables capturing past crisis experience, i.e. whether countries have experienced systemic banking or currency crises in the previous 30 years. It is often argued that countries that have experienced such crises in the past tend to learn from earlier mistakes and avoid allowing such vulnerabilities to build up again. Past crises experience should therefore reduce the negative effects of the current one. However, it can also be argued that recurring crises reflect weak institutions and lack of credibility, which takes a long time to recuperate. Hence, past crises experience can make countries more vulnerable to rapid loss of confidence once a new crisis hits. The links between past crises experience and the current financial crisis are therefore not obvious.

\section{Monetary and exchange rate regimes}

Although no exchange rate peg has been dismantled in the current global crisis, such a collapse has marked many crises in the last two decades, and was often linked to severe banking, corporate or sovereign debt crises. Many commentators have also argued that the exchange rate regime played a key role in the current crisis. Thus, some have argued that euro-membership was crucial in preventing a complete collapse in Ireland, Malta and some of the Southern European countries, while others have argued that the flexible exchange rate regime played a key role in the banking collapse and large contraction in activity experienced in Iceland. Others have, however, highlighted the benefit of a flexible exchange rate for supporting the post-crisis recovery. At the same time, some have argued that the strong focus on inflation control that comes with the inflation targeting regime played an important detrimental role in the build up of vulnerabilities in the run up to the financial crisis in some of the inflation targeting countries, with Iceland a particular case in point.

As a final set of initial conditions, we therefore include indicator variables capturing different monetary and exchange rate regimes within the country sample. The aim of including these regime variables is to analyse to what extent different monetary regimes played a role in the crisis and whether any particular regime reduced or added to the impact of 
the crisis, after controlling for the initial conditions discussed above. ${ }^{17}$ As discussed in the previous section, the country sample includes 16 countries that have a common monetary policy and currency through EMU membership. In addition, there are 8 countries following some type of a unilateral exchange rate peg, either through a currency board or other softer forms of a fixed exchange rate regime. Finally, there are 22 countries with a floating exchange rate, of which 19 follow an explicit IT framework and the others broadly following a framework similar to IT.

\subsection{Descriptive statistics}

Before turning to the formal analysis of the key determinants of the economic impact from the global crisis, it can be useful to look for patterns in the data that may suggest what to expect from a more formal analysis. Table 2 therefore reports average values for all the variables analysed in the paper for the whole country sample and for various interesting country groups.

First, looking at the whole country sample, Table 2 shows that the average output loss in the crisis was $5.5 \%$, whereas the average consumption loss was slightly smaller or $4.4 \% .^{18}$ This indicates that output contraction in the global crisis during our sample period was less than the $6.3 \%$ average for a severe recession in the period 1960-2007 in the 21 OECD country sample analysed in Claessens et al. (2009). The consumption contraction is, on the other hand, much larger in the current crisis than the $1.2 \%$ average they report. This large consumption contraction is therefore a key characteristic of the recent global crisis and underlines the importance of looking beyond measures of output losses. The average duration of the contraction period for the whole country sample ranges from roughly 3 quarters for consumption to closer to 4 quarters for output. The average frequency of a systemic banking crisis was $28 \%$, while a currency crisis only occurred in $4 \%$ of the sample. ${ }^{19}$

Looking at different country groups, it appears that despite greater incidence of banking system crises, the contraction in economic activity was smaller in the industrial countries than in the less developed countries. This might at first glance seem at conflict with the previous claim that this crisis, unlike most previous financial crises, has hit more developed countries harder than less developed countries. This, however, simply reflects the choice of including only medium-to-high income countries in the analysis. The table also shows that very small open economies and countries with unilateral exchange rate pegs were hit particularly hard. Overall, these descriptive statistics suggest that countries whose real economy suffered the most had significant macroeconomic imbalances prior to the crisis, were highly leveraged, and had less flexible exchange rates, whereas countries which had the

\footnotetext{
${ }^{17}$ For example, Berkmen et al. (2009) find evidence that countries with exchange rate pegs experienced a more severe contraction than countries with more flexible exchange rate regimes. Against this, the results in Coulibaly (2009) indicate that countries within currency unions are less likely to experience a currency crisis.

${ }^{18}$ The variation in consumption loss across the country sample is however much larger than the variation in output loss: the standard deviation of consumption loss equals $8.7 \%$ while the standard deviation of output loss equals $5.8 \%$.

${ }^{19}$ The real economy crisis indicators are positively correlated, but not overwhelmingly so. The correlations range from 0.39 between the duration of output and consumption loss to 0.78 between the depth of output and consumption loss. The correlations between the banking and currency crises incidences and the correlations of those indicators with the real economy indicators are all well below 0.3 .
} 
greatest banking and currency crises incidences tend to be those who had large and integrated financial systems and large macroeconomic imbalances prior to the crisis. The next section takes a more formal view on these possible links.

\section{Empirical results}

In this section, we move on to a more formal analysis of the relevance of different initial conditions in explaining the depth and duration of the output and consumption contraction, using cross-country regressions, and the probability of a systemic banking and currency crisis, using cross-country probit regressions. The two following sections report the main results, while Section 3.3 reports some sensitivity analysis. The economic interpretation of the main results is relegated to Section 3.4.

Note that the explanatory variables predate the crisis and the analysis is therefore an attempt to identify what factors were important in predicting the depth and duration of the contraction and whether countries experienced banking or currency crisis or both. Furthermore, with the large number of potential explanatory variables included in this study and limited guidance from theory on exactly what factors to include, we necessarily had to undertake some experimentation before arriving at the preferred baseline specifications presented. Thus, all the potential variables were tested but only those found to be statistically significant at conventional levels are retained.

\subsection{The real economy effects of the crisis}

Tables 3-6 present the main results, i.e. the preferred baseline specifications and the marginal contributions of additional dummy variables for different monetary and exchange rate regimes. As the tables show, we are able to explain up to three-quarters of the cross-country variation in output and consumption loss with a limited set of pre-crisis indicators. Thus, we immediately obtain the important result that initial conditions have mattered in this crisis, unlike the conclusions drawn by Claessens et al. (2010) and Rose and Spiegel (2009a, b). ${ }^{20}$

\section{The depth of the contraction}

The macro channel seems to have played a particularly important role in determining the depth of the real economy contraction during the current crisis, both through macroeconomic volatility and macroeconomic imbalances in the run up to the crisis. This is especially true for inflation which seems to capture factors that were crucial in determining how large the contraction in output and consumption turned out to be. The baseline results (Specification 1 in Tables 3 and 4) suggest that a 1 percentage point higher inflation prior to the crisis coincided with 1.6 percentage point deeper contraction in output and a 2.4 percentage point deeper contraction in consumption, respectively. The baseline results also suggest that output

\footnotetext{
${ }^{20}$ As the tables show, we are only able to explain one-third to half of the cross-country variation in crisis duration. That we are able to explain less of the country variation in crisis duration than crisis depth probably reflects the fact that the variation in duration across countries is smaller than the variation in depth. Again, this may reflect the fact that the crisis is still being played out in some countries and greater variation in the duration of the crisis can be expected once the crisis is fully completed.
} 
volatility had a sizeable effect, with a 1 percentage point higher standard deviation in the output gap coinciding with a 3 percentage point larger output contraction. There are also effects from private sector leverage, with a 10 percentage point higher leverage relative to GDP coinciding with a 0.2 percentage point deeper contraction in output. However, a more flexible exchange rate seems to have contributed to a smaller output contraction: a 1 percentage point higher standard deviation of the effective nominal exchange rate coincided with a 0.9 percentage point smaller contraction in output. The macro channel also had an effect on the consumption contraction through the current account balance, with the baseline results in Table 4 implying that a 10 percentage point better current account position leading to the crisis coincided with a 2.5 percentage point smaller consumption contraction.

There is also a role for the trade and financial channels in determining the extent of the output and consumption contractions. Thus, closer ties to the world economy, through a 0.1 higher correlation of the domestic and world business cycle, coincided with a 0.7 percentage point deeper output contraction, while countries with bigger banking systems tended to have a larger consumption contraction: a country with a banking system that was 1 GDP larger than the average country tended to have a 1.3 percentage point larger contraction in consumption. In addition, we find that countries which experienced a systemic banking crisis in the past tended to have a 3.3 percentage point larger consumption contraction compared to countries which have not experienced such a crisis in the past 30 years.

Finally, our results suggest that countries with some kind of unilateral exchange rate pegs were hit particularly hard by the crisis, while we find no significant additional effects for the EMU countries. Countries with floating exchange rates came out better, in particular if they also had a formal inflation target. Thus, countries outside EMU with an exchange rate peg experienced an almost 8 percentage point larger contraction in consumption compared to other countries, while countries with an inflation target tended to have a 2.5 percentage point smaller contraction in output and 3.2 percentage point smaller contraction in consumption.

\section{The duration of the contraction}

We also find that the macro channel played a key role in determining the length of the crisis (Specification 1 in Tables 5 and 6). Again, we find that higher inflation in the run up to the crisis is reflected in a more protracted economic impact, with a 1 percentage point higher inflation coinciding with a roughly 0.3 quarters longer contraction in output and 0.5 quarters contraction in consumption, respectively. Higher government debt prior to the crisis also seems to have coincided with a longer output contraction: a 10 percentage point higher debt ratio coincided with a 0.1 quarter longer output contraction. Just as with the depth of the crisis, we find that greater exchange rate variability tended to coincide with a more rapid recovery: a 1 percentage point higher standard deviation in the nominal exchange rate coincided with a 0.3 quarters shorter output contraction and a 0.2 quarters shorter consumption contraction.

We also find some role for the financial channel in determining the length of the output contraction. Thus, the more financially open countries tended to experience a somewhat longer contraction, although the effects are quite small. For example, increasing 
our measure of financial openness by 1 GDP lengthens the output contraction by 0.03 quarters. There are also negative effects from the extent of capital inflows: increasing the ratio of capital inflows to GDP by 10 percentage points, coincides with a 0.7 quarters longer output contraction. However, we find that countries more open to trade experienced a shorter output contraction: increasing the share of trade to GDP by 10 percentage points reduces the duration of the output contraction by 0.1 quarter. The results also indicate that countries which have experienced a currency crisis in the past tended to have a 0.7 quarters longer output contraction than countries which had not experienced such a crisis in the past 30 years.

Finally, we find no additional effects from the monetary and exchange rate regime dummies, except that countries with unilateral exchange rate pegs experienced a 1 quarter longer consumption contraction than countries with floating exchange rates or peg within EMU.

\subsection{The probability of a banking and currency crisis}

To estimate the probability of a systemic banking or a currency crisis, we estimate a multivariate ordered probit model. Tables 7-9 report the results for a banking, currency and twin crisis, respectively. ${ }^{21}$ Since probit coefficients are difficult to interpret, we also report the marginal effects measured as a one-unit change in the regressors on the probability of a crisis, evaluated at the mean of the data. ${ }^{22}$ However, for binary regressors, we report the effect of a change from 0 to 1 on the probability of a crisis. For the twin crisis specification, we only report the marginal effects on the probability of a banking or currency crisis, as the marginal effects on the probability of a twin crisis were extremely small, with twin crises found to be highly unlikely in this data set. The marginal effects on the probability of no crisis were therefore practically identical (but with opposite signs) to the marginal effects of either a banking or currency crisis. The tables also report some diagnostic statistics, including the success of correctly predicting a crisis (using a cut-off point of $50 \%$ ) and a measure of improvement over a simple constant-probability model (a probit model which only includes a constant).

Before proceeding to individual results, it is important to note that the estimation results for the currency crisis incidences need to be interpreted with some caution as the frequency of such crises is very low in the country sample (two currency crises and one twin crisis). These results should therefore be thought more of as indicative. This is much less of a problem for the estimation of a banking crisis, where there are 13 crisis observations $(28 \%$ of the sample).

\footnotetext{
${ }^{21}$ For the banking and currency crisis specifications, the indicator variable takes on the value 1 if a banking (currency) crisis occurs and 0 otherwise. For the twin crisis specification the indicator variable takes on the value 0 if neither a banking nor currency crisis occurs, one if either a banking or currency crisis occurs and 2 if a twin crisis occurs. We also tried separating the banking and currency crisis incidence in the crisis indicator (thus allowing four mutually exclusive outcomes: no crisis, a banking crisis, a currency crisis and a twin crisis). The results obtained are very similar to those reported. In particular, the same variables remain significant in both specifications.

${ }^{22}$ Thus, for single-digit percentages the unit change measures a rise of 1 percentage point, while for double-digit or higher percentages the unit change measures a rise of 10 percentage points. For GDP per capita the unit change measures a rise of 1 thousand US dollars.
} 


\section{Determinants of a banking crisis}

The variables that significantly predict a systemic banking crisis are reported in Table 7. First, higher GDP per capita is found to have coincided with a higher probability of a banking crisis. This finding simply reflects the fact that a higher frequency of banking failures in the current financial crisis is found among higher income countries and therefore has no obvious structural implication. More interestingly, a larger banking system prior to the crisis is found to have coincided with higher probability of banking crisis. The marginal effect in the baseline specification (Specification 1) suggests that a 10 percentage point increase in the share of banking system assets to GDP increased the probability of a banking crisis by 1 percentage point. Higher pre-crisis inflation is also associated with a higher probability of a banking crisis. The baseline specification suggests that a 1 percentage point higher inflation in the run up to the crisis raised the probability of a banking crisis by 12 percentage points. Finally, a higher level of foreign reserves relative to GDP is found to decrease the probability of a banking crisis, with the marginal effects suggesting that a 10 percentage point higher ratio of reserves to GDP reduced the probability of a banking crisis by almost 5 percentage points.

The table also reports the effects of adding dummy variables for different monetary regimes. The dummy variables for EMU membership and countries with unilateral exchange rate pegs are not found to be significant, but the dummy variables for IT countries and floating exchange rate countries are found significant at the $5 \%$ critical level. The results suggest that the probability of a banking crisis was 8 percentage points lower for the IT countries than for non-IT countries, other things equal, while the probability was almost 6 percentage points lower for the floating exchange rate countries in general. Note also that the original regressors remain highly significant although that the marginal effects decline somewhat when the regime dummies are added.

\section{Determinants of a currency crisis}

Table 8 reports the variables that significantly predict a currency crisis. It should, however, be noted from the outset that with only two observations of currency crisis, these results by and large pick up the difference between Iceland and Korea, on one hand, and the whole country sample, on the other. Sweeping conclusions cannot therefore be drawn. That said, we again find that GDP per capita needs to be included as a control variable. A larger banking system is also found to have coincided with a higher probability of a currency crisis. There are also positive effects on the probability of a currency crisis from greater exchange rate flexibility and higher fiscal deficits prior to the crisis. However, better institutions, as reflected in greater central bank independence and fewer incidences of past banking crises are found to have coincided with a lower probability of a currency crisis in the current crisis. With the probability of currency crisis extremely low, the marginal effects of changes in the explanatory variables are found to be very small, as shown in Table 8. Furthermore, note that we are not able to add the regime dummies as the maximum likelihood procedure breaks down with the probit model perfectly predicting the binary variable. 


\section{Determinants of a twin crisis}

Finally, Table 9 reports the significant variables predicting a twin crisis. As for the previous two crisis variables, GDP per capita is needed as a control variable. The size of the banking system and the level of inflation are also found to have positively coincided with a twin crisis, with similar marginal effects as found for the baseline specification on the probability of a banking crisis in Table 7. Greater exchange rate variability and higher fiscal deficits are also found to have coincided with higher probability of a currency crisis, similar to the findings in Table 8 , with a 1 percentage point increase in these variables raising the probability of a banking or currency crisis by 6 and 3 percentage points, respectively. However, a 10 percentage point increase in financial deepening is found to have reduced the probability of a banking or currency crisis by roughly 1 percentage point. Finally, none of the regime dummies are found to be significant.

\section{Estimated banking and currency crisis probabilities}

The probit models are quite successful in predicting the banking and currency crises correctly. The three baseline specifications (Specifications 1) predict the incidences correctly in 80-98\% of the cases (using a cut-off point of 50\%), sometimes with some improvements when the regime dummies are added. The baseline specifications also show a significant improvement over a simple constant-probability alternative, with the percentage gain ranging from $30-50 \%$. The models are also generally able to make a sharp distinction between crisis and non-crisis countries: the crisis probabilities tend to lie above $90 \%$ or below $10 \%$ in $59-91 \%$ of the cases and above $80 \%$ and below $20 \%$ in $76-96 \%$ of the cases.

The banking crisis regression in Table 7 correctly predicts a banking crisis in Belgium, Iceland, Ireland, Latvia, Luxembourg, the Netherlands and Switzerland with close to $100 \%$ probability and in the UK with a slightly lower probability, or $70 \%$. The model predicts a banking crisis in Austria and the US with just short of 50\% probability, and assigns an even lower probability to a banking crisis in Denmark (34\%), Russia, (23\%) and Germany (18\%). There are also a few cases of false warnings: the model predicts a banking crisis in Sweden with a $70 \%$ probability and a banking crisis in Estonia, Hungary and Norway with a probability just above $50 \% .^{23}$ A somewhat smaller probability is assigned to a crisis in Spain, or $31 \% .^{24}$ However, as Figure 3(a) shows, only four of the incorrect predictions are larger than two standard errors.

The currency crisis regression in Table 8 predicts a currency crisis in Iceland with a 93\% probability, but fails to predict the currency crisis in Korea (only $15 \%$ probability). It

\footnotetext{
${ }^{23}$ Allen and Moessner (2010) doubt that Sweden and Denmark could have provided effective support to their banks in the absence of swap lines from the Fed after the Lehman Brother's failure and from the ECB a little later as the necessary provision of foreign currency liquidity would have used up most of their reserves. Swedish banks in Estonia received support from their mother companies and the Swedish Riksbank set up swap lines with their Estonian counterpart. Hungary did turn to the IMF and the European Union for considerable support and the European Central Bank and Swiss National Bank set up swap facilities with the Hungarian central bank to provide commercial banks within the country with access to euro and Swiss franc liquidity.

${ }^{24}$ Problems among Spanish saving banks became clear in May 2010, outside of our sample period, when the Bank of Spain seized control of CajaSur and merger plans among the remaining Cajas intensified.
} 
also incorrectly assigns quite a high probability of a currency crisis in Israel (43\%) and Bulgaria $(23 \%)$ - but only the prediction errors for Korea and Israel are found to be significant at the $95 \%$ critical level (Figure 3(b)).

Finally, the probit specification for the twin crisis in Table 9 is better able to predict the banking crisis in Austria, Russia, the UK and the US than the banking crisis specification in Table 7 but seems less certain about the crisis in Latvia (Figure 4). For other countries, the crisis predictions are very similar to those from the banking crisis specification. Of the false banking crisis predictions, the high probabilities of a banking crisis in Hungary and Sweden remain, but the probabilities for Estonia, Norway and Spain decline substantially. Against this, the model incorrectly predicts a crisis in Bulgaria with a 54\% probability. Furthermore, the false currency crisis in Israel has disappeared. Finally, the model predicts the twin crisis in Iceland correctly, with a $79 \%$ probability.

\subsection{Robustness tests}

As a first robustness test, we try retaining the GDP level and GDP per capita as controls in all the baseline regressions in Tables 3-9, capturing the greater crisis impact in higher income countries and smaller countries, as discussed before. In all cases are these variables nonsignificant (except in the banking and currency crisis equations, were the significant GDP per capita variable is already included) and in no case does the inference on other explanatory variables change. With a relatively large number of small countries in our sample, it could also be the case that the small countries are given unduly large weights in the empirical findings, thus somewhat blurring how the global crisis spread from its epicentre in the US to other large countries. To test for the sensitivity of our results to a possible small-country bias we therefore re-estimate all the regressions using weighted least squares, with the log of GDP as a scaling variable. However, we find that our results are insensitive to this and in no case is the inference altered.

We also try adding different country group dummy variables to the baseline regressions, reported in Table 10. First, we add country dummy variables for OECD countries, EU countries, emerging market countries, the central and eastern European countries, and the very small open economies. As Table 10 shows, these dummy variables are found insignificant in almost all cases. Furthermore, the addition of these variables is not found to alter the statistical properties of the other explanatory variables. ${ }^{25}$

Next, we split the country group into income and size quartiles using GDP per capita and GDP levels, respectively, and add dummy variables defining different income and size groups to the baseline regressions. Table 10 reports the estimated coefficients on the dummy variables. The income and size dummies are found to be insignificant in almost all cases, and in all but two cases is the significance of the explanatory variables unaltered: the current account balance becomes insignificant in the consumption-loss equation when a country

\footnotetext{
${ }^{25}$ Following Lane and Milesi-Ferretti (2010), we also try adding a country group for small countries with large financial centres (defined as countries with financial openness ratio exceeding $800 \%$ ), which have been hit particularly hard by this crisis. These 10 countries are Belgium, Cyprus, Hong Kong, Iceland, Ireland, Luxembourg, Malta, the Netherlands, Switzerland, and the UK. In no case is this dummy variable found significant, nor does it alter the inference on the other explanatory variables.
} 
dummy for small countries is added and foreign reserves become insignificant in the bankingcrisis equation when a country dummy for low income countries is added.

The final part of Table 10 adds continental dummies to the baseline regressions. The African dummy variable is found to be highly significant in all the regressions, but as South Africa is the only African country in the sample, this dummy variable simply serves as a dummy variable for that country. The other continental dummies are found to be insignificant in most other cases, and in all cases are the results from the baseline regressions unaffected.

As a final robustness test, we re-estimate all the baseline regressions dropping one observation at a time and check whether the explanatory variables continue to be significant. We find that they do in almost all cases. There are, however, four exceptions: dropping Hong Kong from the sample makes foreign reserves insignificant in the bank-crisis equation, dropping Luxembourg from the sample makes financial openness insignificant in the outputduration equation and financial deepening insignificant in the twin-crisis equation, and dropping Norway from the sample makes fiscal balances insignificant in the twin-crisis equation. We also do a similar sensitivity analysis for the regime dummies. The inference on the IT and exchange rate peg dummies is found to be robust to variations in the country sample, whereas the dummy variable for floating exchange rate countries become marginally insignificant in the consumption-loss equation in some cases, and three other cases give a $p$ value close to 0.2 (Russia, South Africa and Turkey). However, leaving out Iceland in the consumption-loss equation results in a highly significant dummy variable for floating exchange rate countries.

\subsection{Interpreting the results}

In this section we offer an interpretation of what we think are the key results of our paper. Before proceeding it should, however, be emphasised that this paper is not a general analysis of financial, banking or currency crises, but focuses only on the current crisis and its consequences. Therefore, some of the results found in this paper may be specific to this crisis and need not generalise to others. However, there are some interesting results worth highlighting that may be relevant to understanding not only this crisis but financial crises in general, and have some important policy implications.

One of the most striking results we obtain is how strong the effects of inflation just prior to the crisis seems to be, with the inflationary-effect generally the most significant effect of all the initial conditions. Thus, countries with higher inflation tended to experience a deeper and more protracted contraction, and were more vulnerable to the risk of a systemic banking and currency crises. We believe that this inflationary-effect captures the degree of macroeconomic imbalances in the run up to the crisis and policy constraints that countries faced in their response to the crisis. The scope for monetary policy easing and its transmission to the real economy is affected by current inflationary pressures and to what degree inflation expectations are sufficiently anchored. Countries with higher inflation in the run up to the crisis were therefore likely to be in a less favourable position to use monetary stimulus 
measures to counteract the economic impact of the global crisis than countries were inflation was already well anchored. ${ }^{26}$

Looking at other measures of economic imbalances and vulnerabilities, the general story emerges that the greater the macroeconomic imbalances in the run up to the crisis, the more painful it turned out to be. Higher private sector leverage, larger current account deficits, ${ }^{27}$ more output volatility, or lower foreign reserves all seemed to contribute in one way or another to a deeper contraction and increased risk of a systemic banking crisis. It is interesting to note that the level of foreign reserves did not have any significant effect on the probability of a currency crisis. Instead we find that lower reserves increased the risk of a banking crisis, which may reflect the interaction between very large banking systems and limited ability of the domestic monetary authority to provide foreign currency liquidity services, often pointed out as a major vulnerability during the current crisis. We note, however that the effect of reserves is not robust to the exclusion of Hong Kong from the country sample and that the interaction between access to central bank swap lines and actual reserve holdings can be difficult to control for.

We also find that the fiscal position played a role in this crisis. Thus, we find that greater government debt in the run up to the crisis coincided with a longer output contraction. This seems logical: the worse the debt position of the government, the less the fiscal space for supporting the recovery after the crisis hit. We also find that larger fiscal deficits prior to the crisis tended to increase the risk of a banking or currency crisis. Again, this seems logical: larger deficits tend to go hand in hand with higher risk premia which would presumably rise sharply once the crisis hit and exacerbate uncertainty that could eventually lead to panic and a full blown currency crisis. The significance of this effect depends, however, on the inclusion of Norway in the country sample.

Furthermore, we also find that the size of the banking system played an important role. First, we find that the larger the banking system, the larger the consumption contraction tended to be. This is consistent with the interpretation that once the crisis hit, governments needing to support large banking systems had less fiscal space to support domestic demand. It can also reflect increased households' dependence on credit for consumption financing in countries with larger banking systems. We also find that larger banking systems increased the probability of a banking and currency crises. However, our results suggest that a more

\footnotetext{
${ }^{26}$ This finding on the importance of inflation may to a certain extent be interpreted as being at odds with the recent recommendation of the IMF's chief economist, Olivier Blanchard, and his co-authors (2010) who suggest that higher inflation targets, and therefore higher average inflation, makes crisis responses easier by increasing the room for lowering interest rates to counteract the crisis. Our results suggest that higher inflation in the run up to this crisis made it worse, not better, and these results seem robust to different crisis measures and various robustness checks. In particular, it is worth emphasising that they are not driven by few observations of extremely high inflation (the highest observed inflation in our sample is $10 \%$ and the average inflation rate across the country sample is $3.4 \%$ ).

${ }^{27}$ Interestingly, we find that higher current account deficits tend to exacerbate the consumption contraction but have no effects on the output contraction. This seems logical as higher current account deficits call for an adjustment in domestic demand, with a net export adjustment (especially through import compression) reducing the effect on output.
} 
developed financial system reduced the risk of a banking or currency crisis. This last finding, however, is not robust to excluding Luxembourg from the country sample.

We find mixed results on whether stronger ties to the global economy through trade and finance exacerbated the crisis or not. Thus, stronger trade and financial linkages coincided with a larger and longer output contraction, as the global financial panic and the sudden reversal of capital inflows and sharp contraction in global demand that followed hit those countries especially hard, which relied more heavily on these capital flows or were more open to trade. The significant effect of financial openness on the persistence of the output contraction is, however, very much driven by the extremely large external balance sheet of Luxembourg and excluding Luxembourg from the sample leaves this effect insignificant. Thus, any interpretation of a causal link between financial openness and exposure to the global crisis will need to take account of the sensitivity to this large outlier. The significance of capital inflows however remains when Luxembourg is excluded from the sample. At the same time, we find that countries more open to trade recovered faster from the crisis. This probably reflects the fact that these countries benefitted more by the relatively rapid reversal in global demand (especially in Asia) in 2009 than countries less open to trade.

We also find some mixed results on the role of exchange rate flexibility. While our results suggest that greater exchange rate flexibility reduced both the depth and the duration of the contraction, it increased the risk of a banking or currency crisis. Thus, exchange rate flexibility facilitated the economic adjustment to the crisis through greater relative price flexibility, but at the same time made countries more vulnerable to a banking or currency crisis. Flexibility was thus a double-edged sword in this sense. This is further corroborated by the effects of different unilateral exchange rate regime dummies: we find that countries with unilateral exchange rate pegs had a particularly large and protracted consumption contraction. This, however, only applies to countries with exchange rate pegs outside a monetary union: we find no evidence that EMU membership led to additional negative effects of the crisis comparable to the effects we find for the unilateral peg countries. ${ }^{28}$ At the same time we find that countries with a formal inflation target (and sometimes floating exchange rates in general) tended to have a smaller contraction and were less likely to have a systemic banking crisis. $^{29}$

We also find that countries that have experienced a banking or currency crisis in the past tended to have a deeper and longer consumption contraction and were more likely to suffer a currency crisis. No evidence is found that suggests that past crises experience reduced the probability of a banking system crisis in the current crisis. Thus, learning from past crises does not seem to have benefitted in the current crisis or, at least, seems to have been outweighed by the possible negative effects of past crises experience on credibility of current institutions to deal with the crisis. The importance of sound institutions is also suggested by

\footnotetext{
${ }^{28}$ Furthermore, we do not analyse possible effects from EMU membership on the probability of sovereign debt crisis. Effects from the turmoil in 2010 surrounding the sustainability of sovereign debt of countries within the euro area lie outside of our sample period.

${ }^{29}$ This is consistent with Carvalho Filho (2010), who also finds beneficial effects of inflation targeting during the current crisis.
} 
our finding that greater central bank independence reduced the probability of a currency crisis. Other institutional factors are not found significant, however.

Our results indicate a non-significant role for some variables which have been widely discussed as having played an important role in determining the economic impact of the crisis. Especially, it is noteworthy that we find no role for access to the Fed's dollar liquidity facility for the likelihood of a systemic banking crisis. The establishment of central bank swap lines has been widely praised for having effectively relieved US dollar liquidity stresses in money and FX swap markets and hindering global financial instability from becoming much more serious (see e.g. Allen and Moessner, 2010). Our results should however not be interpreted as rejecting the importance of these international facilities as we cannot measure what the outcome would have been in their absence. We could also be overlooking the role played by the access to central bank swap lines in limiting the scale of a systemic banking crisis as our measurement of banking crises does not make any distinction between a banking crisis and a total banking system collapse. Neither do we find a role for our three measures of trade structure (the share of manufacturing exports, trade diversification and trade concentration), which might emerge if the country sample would be expanded to include more developing countries.

While our finding that exchange rate flexibility seems to facilitate the real adjustment to the crisis while at the same time increasing the risk of currency crisis is plausible, a comment with respect to the apparent lack of separate effect of EMU membership is also in order. For example, it is important to keep in mind that the pre-crisis initial conditions are unlikely to be exogenous to the exchange rate regime in a given country. In addition, within a monetary union it is probable that a larger share of external debt and the current account deficit would be in domestic currency and thus less likely to be a source of vulnerability. Furthermore, it seems obvious that EMU membership protected countries against a currency crisis and may thus have helped mitigating the real impact of the crisis through that channel (cf. Cecchetti et al., 2009, who find that output losses tend to be much higher in currency crises episodes). Finally, as previously mentioned our measure of banking crises does not discriminate between the size of different banking crises in our sample. It could for example be argued that the large banking collapse in Iceland could have been contained to some extent had Iceland been a member of EMU, with stronger institutional support, for example through the greater ability of the ECB to provide liquidity support.

Finally, in terms of specific crisis episodes, we are able to predict quite accurately the extent of the crisis in some of the countries hit particularly hard (both in terms of the real economy impact and the banking and currency crisis incidences), such as Iceland, Ireland, and the three Baltic countries (see Figures 1-4). As can be seen in Figure 5, our statistical models suggest that the main reasons for the large and persistent contraction in output and consumption in the Baltic countries are the higher-than-average rate of inflation and, to a lesser extent, greater underlying economic volatility and higher current account deficits, whereas in Iceland and Ireland the main reasons were in addition to the inflationary-effect, the greater-than-average financial exposure of these two countries (larger capital inflows and higher private sector leverage in the case of Iceland, larger financial openness and limited 
exchange rate flexibility in the case of Ireland, and the very large banking systems in both countries).

However, some countries did worse than our statistical models predict. For example, our models predict a less protracted output contraction in Denmark and a smaller consumption loss in Russia, while assigning a relatively small probability of a banking crisis in either country. Our probit specifications also fail to spot the currency crisis in Korea. ${ }^{30}$ At the same time, there are some countries that seem to have done better than predicted by our statistical models. For example, we find that the real economy impact in Australia and Poland was smaller than the initial conditions suggest and obtain quite a high probability of a banking crisis in Sweden which did not materialise.

\section{Conclusions}

The goal of this paper is to try to identify which factors were important in determining the macroeconomic impact of the recent global financial crisis, and why some countries experienced a systemic banking and currency crises while others escaped more lightly. We do this by identifying a broad set of potential pre-crisis explanatory variables in a cross-section of 46 medium-to-high income countries, framed within four possible channels through which the crisis spread out over from financial markets through the real economy all over the world: a financial channel, a trade channel, a macro channel and an institutional channel.

We find an important role for the macro channel in the propagation of the shock and the extent of the crisis, through various measures of pre-crisis macroeconomic imbalances and vulnerabilities. Thus, we find that countries that, in the run up to the crisis, had higher inflation, larger current account deficits, a more leveraged private sector, greater output volatility, or a poorer fiscal position tended to experience some combination of a deeper or more protracted contraction in output or consumption, and were more likely to experience a systemic banking or currency crisis.

We also find an important role for the financial channel. Thus, countries with relatively large banking systems or stronger global financial linkages tended to experience a deeper or longer contraction in output or consumption. In addition we find that large banking systems significantly increased the probability of a systemic banking or currency crisis.

Our results on the trade channel are mixed. While we find that countries with business cycles that were closely connected to the global business cycle experienced a deeper output contraction, we also find that the output contraction tended to be shorter in those countries that were more open to trade.

We also get mixed results for the role of exchange rate flexibility. We find that greater exchange rate flexibility coincided with a smaller and shorter contraction, while at the same time increasing the probability of a currency crisis or a combination of a systemic banking and currency crisis. We also find that countries with unilateral exchange rate pegs had a

\footnotetext{
${ }^{30}$ Given the relatively small real economy impact on Korea, this could suggest a problem in our definition of a currency crisis, which may incorrectly be signalling a currency crisis in Korea rather than suggesting a failure of our probit specification to spot the crisis.
} 
particularly large and protracted consumption contraction, while no comparable evidence is found for the EMU countries. This suggests that countries with exchange rate pegs outside a monetary union were particularly vulnerable in the current financial crisis. We also find that countries with a formal inflation target (and sometimes floating exchange rates in general) tended to have a smaller contraction and were less likely to have a systemic banking crisis.

Finally, we find that past experience of a systemic banking or currency crises had no beneficial effect during this crisis. In fact, our results suggest that past crises-countries tended to have a deeper and longer contraction and were more likely to suffer a currency crisis. We conclude that the possible positive learning effects from past crises is outweighed by loss of credibility resulting from past crises experience. We also find some tentative evidence suggesting the importance of institutional quality in that countries with more independent central banks were less likely to experience a currency crisis.

The policy implications of these results seem clear and perhaps uncontroversial. Thus, the key factors in escaping this global crisis relatively unscathed seem to have been to maintain sound macroeconomic conditions, i.e. avoid allowing large economic imbalances to build up, and not allowing the banking system to get too large relative to the economy. Our results suggest that economies that achieved this were better able to absorb the financial shock and faster to recover from the crisis. Exchange rate flexibility also seemed to have helped reducing the real economy impact and expedite the recovery, but increased the risk of a currency crisis at the same time. Exchange rate flexibility, jointly with a formal inflation target, however, seemed to have helped reduce the risk of a systemic banking crisis. Although we find no significant effects of EMU membership, the fact that the additional negative effects of unilateral exchange rate pegs are not found in the case of the EMU countries suggests that fixed exchange rates through euro membership mitigated the negative effects of exchange rate pegs in the crisis. EMU membership can also have helped through preventing the occurrences of currency crises and reducing the size of possible banking crises within member countries. 
Table 1. Country sample

\begin{tabular}{|c|c|c|c|}
\hline Australia & France & Lithuania & Slovakia \\
\hline Austria & Germany & Luxembourg & Slovenia \\
\hline Belgium & Greece & Malta & Spain \\
\hline Bulgaria & Hong Kong & Mexico & Sweden \\
\hline Canada & Hungary & Netherlands & Switzerland \\
\hline Chile & Iceland & New Zealand & Taiwan \\
\hline Croatia & Ireland & Norway & Thailand \\
\hline Cyprus & Israel & Poland & Turkey \\
\hline Czech Republic & Italy & Portugal & United Kingdom \\
\hline Denmark & Japan & Romania & United States \\
\hline Estonia & Korea & Russia & \\
\hline Finland & Latvia & South Africa & \\
\hline \multicolumn{4}{|c|}{ Different country groups } \\
\hline \multicolumn{4}{|c|}{$\begin{array}{l}\text { Industrial countries } \\
\text { Australia, Austria, Belgium, Canada, Denmark, Finland, France, Germany, Greece, Hong Kong, } \\
\text { Iceland, Ireland, Israel, Italy, Japan, Korea, Luxembourg, Netherlands, New Zealand, Norway, } \\
\text { Portugal, Spain, Sweden, Switzerland, Taiwan, United Kingdom, United States }\end{array}$} \\
\hline \multicolumn{4}{|c|}{$\begin{array}{l}\text { Emerging market economies } \\
\text { Bulgaria, Chile, Croatia, Cyprus, Czech Republic, Estonia, Hungary, Latvia, Lithuania, Malta, } \\
\text { Mexico, Poland, Romania, Russia, South Africa, Slovakia, Slovenia, Thailand, Turkey }\end{array}$} \\
\hline \multicolumn{4}{|c|}{$\begin{array}{l}\text { Central and Eastern European countries } \\
\text { Bulgaria, Croatia, Czech Republic, Estonia, Hungary, Latvia, Lithuania, Poland, Romania, Russia, } \\
\text { Slovakia, Slovenia }\end{array}$} \\
\hline \multicolumn{4}{|c|}{$\begin{array}{l}\text { Very small open economies } \\
\quad \text { Cyprus, Estonia, Iceland, Latvia, Luxembourg, Malta, Slovenia }\end{array}$} \\
\hline \multicolumn{4}{|c|}{$\begin{array}{l}\text { Australia, Canada, Chile, Czech Republic, Hungary, Iceland, Israel, Korea, Mexico, New Zealand, } \\
\text { Norway, Poland, Romania, South Africa, Sweden, Switzerland, Thailand, Turkey, United Kingdom }\end{array}$} \\
\hline $\begin{array}{l}\text { Unilateral exchar } \\
\text { Bulgaria, Croa }\end{array}$ & $\begin{array}{l}\text { pegs } \\
\text { imark, Estoni }\end{array}$ & Latvia, Lithu & \\
\hline
\end{tabular}


Table 2. Average values for different country groups

\begin{tabular}{|c|c|c|c|c|c|c|c|c|}
\hline & ALL & IND & EME & CEA & VSOE & EMU & IT & PEG \\
\hline Depth of output contraction & 0.055 & 0.040 & 0.076 & 0.098 & 0.119 & 0.051 & 0.036 & 0.114 \\
\hline Depth of consump. contract. & 0.044 & $\underline{0.011}$ & 0.090 & 0.125 & 0.138 & $\underline{0.016}$ & 0.025 & 0.162 \\
\hline Dur. of output contraction & 3.739 & 3.741 & 3.737 & 3.583 & 4.857 & 3.938 & 3.368 & 4.250 \\
\hline Dur. of consump. contract. & 3.109 & 2.741 & 3.632 & 4.000 & 3.857 & 3.000 & 2.684 & 4.625 \\
\hline Frequency of banking crisis & 0.283 & 0.407 & $\underline{0.105}$ & 0.167 & 0.429 & 0.375 & 0.158 & 0.375 \\
\hline Frequency of currency crisis & 0.043 & 0.074 & $\overline{0.000}$ & 0.000 & 0.143 & 0.000 & 0.105 & 0.000 \\
\hline GDP level & 991 & 1,394 & 418 & $\underline{347}$ & 30 & 681 & 638 & 386 \\
\hline GDP per capita & 30.0 & 38.7 & 17.7 & 19.2 & 34.0 & 35.5 & 27.1 & 23.1 \\
\hline Financial deepening & 0.933 & 1.143 & $\underline{0.633}$ & 0.484 & 1.509 & 1.217 & $\underline{0.655}$ & 0.879 \\
\hline Size of banking system & 2.247 & 2.949 & 1.249 & 0.635 & 4.338 & 3.180 & 2.041 & 1.391 \\
\hline Stock market capitalisation & 1.164 & 1.401 & 0.828 & 0.478 & 1.481 & 1.108 & 1.143 & 1.252 \\
\hline Trade openness & 0.863 & 0.764 & 1.004 & 1.027 & 1.112 & 0.948 & 0.691 & 1.190 \\
\hline Output & 0.447 & 0.524 & $\underline{0.337}$ & 0.346 & 0.465 & 0.584 & 0.383 & 0.329 \\
\hline Manufacturing exports share & 0.666 & 0.685 & $\overline{0.639}$ & 0.682 & 0.653 & 0.770 & 0.577 & 0.592 \\
\hline Trade diversification & 0.478 & 0.458 & 0.508 & 0.480 & $\underline{0.570}$ & 0.442 & 0.511 & 0.511 \\
\hline Trade concentration & 0.166 & 0.156 & 0.181 & 0.153 & 0.229 & 0.143 & 0.188 & 0.171 \\
\hline Financial openness & 10.545 & 15.117 & 4.047 & 2.116 & 42.907 & 22.834 & 3.680 & 5.229 \\
\hline Capit & 0.059 & 0.040 & 0.087 & 0.081 & 0.038 & 0.043 & 0.054 & 0.122 \\
\hline Access to US\$ liquidity & 0.609 & 0.852 & 0.263 & 0.167 & 0.571 & 1.000 & 0.474 & 0.125 \\
\hline Output volatility & 0.020 & 0.015 & 0.026 & 0.028 & 0.023 & 0.015 & 0.021 & 0.028 \\
\hline ariability & 0.031 & 021 & 0.044 & 0.043 & 0.019 & 0.014 & 0.039 & 0.045 \\
\hline Exchange rate noise & 0.137 & 0.097 & 0.209 & 0.211 & 0.177 & $\underline{0.101}$ & 0.155 & 0.203 \\
\hline Inflation rate & 0.034 & 0.022 & 0.050 & 0.056 & 0.044 & 0.024 & 0.034 & $\underline{0.058}$ \\
\hline Current account balance & -0.030 & 0.006 & -0.082 & -0.101 & -0.124 & -0.030 & -0.015 & $-\overline{-0.085}$ \\
\hline Size of foreign reserves & 0.173 & $\overline{0.110}$ & 0.263 & 0.213 & $\overline{0.311}$ & 0.131 & 0.135 & 0.300 \\
\hline Financial leverage & 1.494 & 1.607 & 1.332 & 1.399 & 1.842 & 1.464 & 1.512 & 1.662 \\
\hline Fiscal balance & 0.010 & 0.018 & 0.000 & $\underline{-0.007}$ & 0.018 & 0.000 & 0.018 & 0.021 \\
\hline Government debt & 0.461 & 0.555 & 0.327 & $\overline{0.269}$ & $\underline{0.272}$ & 0.578 & 0.415 & 0.166 \\
\hline Government effectivenes & 1.176 & 1.601 & 0.571 & 0.491 & 1.260 & 1.284 & 1.215 & 0.797 \\
\hline Regulatory quality & 1.167 & 1.448 & 0.767 & 0.781 & 1.345 & 1.324 & 1.104 & 1.010 \\
\hline Legal structure & 7.299 & $\mathbf{7 . 9 3 0}$ & 6.403 & 6.244 & 7.493 & 7.494 & 7.285 & 6.912 \\
\hline Central bank independence & 0.831 & 0.822 & 0.843 & 0.858 & 0.807 & 0.845 & 0.806 & 0.835 \\
\hline Credit market regulation & 8.879 & 8.895 & 8.855 & 8.892 & $\underline{9.300}$ & 8.766 & 8.884 & 9.228 \\
\hline Labour market regulation & 5.976 & 6.085 & 5.821 & 5.921 & $\overline{5.994}$ & 5.403 & 6.213 & 6.212 \\
\hline Business regulation & 6.853 & 7.460 & 5.991 & 5.964 & 6.752 & 6.824 & 6.989 & 6.526 \\
\hline Economic freedom index & 7.402 & 7.648 & 7.052 & 6.974 & 7.400 & 7.383 & 7.403 & 7.321 \\
\hline Past banking crisis & 0.522 & $\overline{0.296}$ & 0.842 & 1.000 & 0.429 & 0.250 & 0.632 & 0.750 \\
\hline Past currency crisis & 0.435 & $\overline{0.333}$ & 0.579 & 0.500 & 0.429 & $\overline{0.313}$ & 0.526 & 0.625 \\
\hline
\end{tabular}

The values for the current and past banking and currency crisis and access to US\$ liquidity report the average number of countries in each group which experienced a banking and currency crisis. All variables are measured in percentages, except the duration of the output and consumption contractions (in quarters), the GDP level and per capita (in billions and thousand of US dollars respectively), trade diversification, trade concentration and central bank independence (indices between 0 and 1), government effectiveness and regulatory quality (indices between -2.5 and 2.5 ) and credit market regulation, labour market regulations, business regulation and the economic freedom index (indices between 0 and 10). 'All' denotes the whole country sample, 'IND' denotes the 27 industrial countries, 'EME' denotes the 19 emerging market economies, 'CEA' denotes the 12 central and eastern European countries, 'VSOE' denotes the 7 very small open economies, 'EMU' denotes the 16 EMU countries, 'IT' denotes the 19 inflation targeting countries, and 'PEG' denotes the 8 countries with unilateral exchange rate pegs. Bolded (underlined) numbers denote significant difference between individual group averages and the whole sample average, allowing for different sample variances (a Satterthwaite-Welch $t$-test) using a 5\% (10\%) critical value. 
Table 3. Regression results for the depth of the output contraction

\begin{tabular}{|c|c|c|c|c|c|}
\hline & & & ification & & \\
\hline & (1) & (2) & (3) & (4) & (5) \\
\hline Constant & $\begin{array}{c}-0.093 \\
(0.002) \\
{[0.001]}\end{array}$ & $\begin{array}{c}-0.096 \\
(0.001) \\
{[0.001]}\end{array}$ & $\begin{array}{c}-0.086 \\
(0.002) \\
{[0.001]}\end{array}$ & $\begin{array}{c}-0.089 \\
(0.002) \\
{[0.001]}\end{array}$ & $\begin{array}{c}-0.084 \\
(0.004) \\
{[0.002]}\end{array}$ \\
\hline Output correlation & $\begin{array}{l}0.066 \\
(0.030) \\
{[0.023]}\end{array}$ & $\begin{array}{l}0.063 \\
(0.048) \\
{[0.021]}\end{array}$ & $\begin{array}{l}0.055 \\
(0.055) \\
{[0.042]}\end{array}$ & $\begin{array}{l}0.069 \\
(0.023) \\
{[0.016]}\end{array}$ & $\begin{array}{l}0.060 \\
(0.050) \\
{[0.044]}\end{array}$ \\
\hline Output volatility & $\begin{array}{l}2.981 \\
(0.001) \\
{[0.002]}\end{array}$ & $\begin{array}{l}3.016 \\
(0.001) \\
{[0.001]}\end{array}$ & $\begin{array}{l}2.941 \\
(0.001) \\
{[0.001]}\end{array}$ & $\begin{array}{l}2.754 \\
(0.002) \\
{[0.003]}\end{array}$ & $\begin{array}{l}2.909 \\
(0.001) \\
{[0.002]}\end{array}$ \\
\hline Exchange rate variability & $\begin{array}{r}-0.905 \\
(0.002) \\
{[0.013]}\end{array}$ & $\begin{array}{c}-0.872 \\
(0.003) \\
{[0.019]}\end{array}$ & $\begin{array}{r}-0.700 \\
(0.012) \\
{[0.047]}\end{array}$ & $\begin{array}{r}-0.866 \\
(0.002) \\
{[0.012]}\end{array}$ & $\begin{array}{r}-0.794 \\
(0.007) \\
{[0.025]}\end{array}$ \\
\hline Inflation rate & $\begin{array}{l}1.562 \\
(0.000) \\
{[0.002]}\end{array}$ & $\begin{array}{l}1.553 \\
(0.000) \\
{[0.002]}\end{array}$ & $\begin{array}{l}1.406 \\
(0.000) \\
{[0.002]}\end{array}$ & $\begin{array}{l}1.453 \\
(0.000) \\
{[0.003]}\end{array}$ & $\begin{array}{l}1.463 \\
(0.000) \\
{[0.003]}\end{array}$ \\
\hline Financial leverage & $\begin{array}{l}0.023 \\
(0.012) \\
{[0.001]}\end{array}$ & $\begin{array}{l}0.024 \\
(0.012) \\
{[0.001]}\end{array}$ & $\begin{array}{l}0.028 \\
(0.002) \\
{[0.004]}\end{array}$ & $\begin{array}{l}0.022 \\
(0.017) \\
{[0.011]}\end{array}$ & $\begin{array}{l}0.025 \\
(0.008) \\
{[0.002]}\end{array}$ \\
\hline EMU dummy & & $\begin{array}{l}0.005 \\
(0.661) \\
{[0.617]}\end{array}$ & & & \\
\hline Inflation targeting dummy & & & $\begin{array}{r}-0.025 \\
(0.014) \\
{[0.022]}\end{array}$ & & \\
\hline Exchange rate peg dummy & & & & $\begin{array}{l}0.019 \\
(0.200) \\
{[0.263]}\end{array}$ & \\
\hline Floating exchange rate dummy & & & & & $\begin{array}{c}-0.014 \\
(0.200) \\
{[0.148]}\end{array}$ \\
\hline$R^{2}$ & 0.726 & 0.728 & 0.766 & 0.738 & 0.738 \\
\hline Standard error & 0.032 & 0.033 & 0.030 & 0.032 & 0.032 \\
\hline
\end{tabular}

Numbers in parenthesis are $p$-values based on conventional standard errors, while numbers in brackets are $p$ values based on robust (White) standard errors. 
Table 4. Regression results for the depth of the consumption contraction

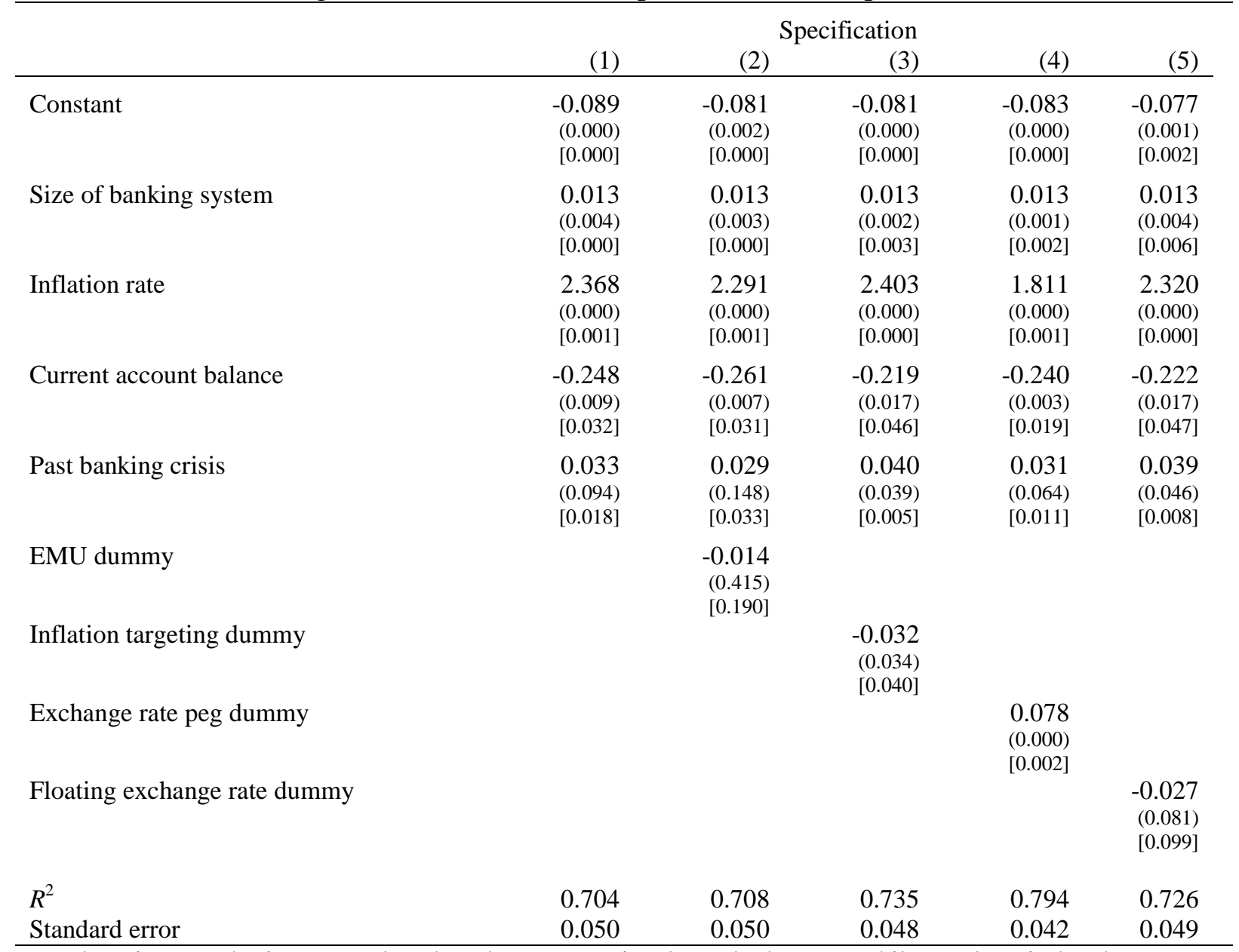

Numbers in parenthesis are $p$-values based on conventional standard errors, while numbers in brackets are $p$ values based on robust (White) standard errors. 
Table 5. Regression results for the duration of output contraction

\begin{tabular}{|c|c|c|c|c|c|}
\hline & $(1)$ & $(2)$ & $\begin{array}{c}\text { pecification } \\
\text { (3) }\end{array}$ & (4) & $(5)$ \\
\hline Constant & $\begin{array}{l}2.465 \\
(0.000) \\
{[0.001]}\end{array}$ & $\begin{array}{l}2.548 \\
(0.000) \\
{[0.001]}\end{array}$ & $\begin{array}{l}2.598 \\
(0.000) \\
{[0.001]}\end{array}$ & $\begin{array}{l}2.477 \\
(0.000) \\
{[0.001]}\end{array}$ & $\begin{array}{l}2.432 \\
(0.002) \\
{[0.004]}\end{array}$ \\
\hline Trade openness & $\begin{array}{r}-0.719 \\
(0.040) \\
{[0.048]}\end{array}$ & $\begin{array}{r}-0.740 \\
(0.034) \\
{[0.013]}\end{array}$ & $\begin{array}{r}-0.749 \\
(0.037) \\
{[0.023]}\end{array}$ & $\begin{array}{r}-0.794 \\
(0.024) \\
{[0.014]}\end{array}$ & $\begin{array}{r}-0.717 \\
(0.044) \\
{[0.025]}\end{array}$ \\
\hline Financial openness & $\begin{array}{l}0.030 \\
(0.000) \\
{[0.000]}\end{array}$ & $\begin{array}{l}0.033 \\
(0.000) \\
{[0.000]}\end{array}$ & $\begin{array}{l}0.029 \\
(0.000) \\
{[0.000]}\end{array}$ & $\begin{array}{l}0.029 \\
(0.000) \\
{[0.000]}\end{array}$ & $\begin{array}{l}0.030 \\
(0.001) \\
{[0.000]}\end{array}$ \\
\hline Capital inflows & $\begin{array}{l}7.220 \\
(0.002) \\
{[0.001]}\end{array}$ & $\begin{array}{l}7.812 \\
(0.001) \\
{[0.000]}\end{array}$ & $\begin{array}{l}7.144 \\
(0.003) \\
{[0.000]}\end{array}$ & $\begin{array}{l}6.932 \\
(0.003) \\
{[0.000]}\end{array}$ & $\begin{array}{l}7.288 \\
(0.003) \\
{[0.001]}\end{array}$ \\
\hline Exchange rate variability & $\begin{array}{r}-26.148 \\
(0.001) \\
{[0.001]}\end{array}$ & $\begin{array}{r}-30.116 \\
(0.000) \\
{[0.000]}\end{array}$ & $\begin{array}{r}-25.069 \\
(0.002) \\
{[0.000]}\end{array}$ & $\begin{array}{r}-25.895 \\
(0.001) \\
{[0.000]}\end{array}$ & $\begin{array}{r}-26.507 \\
(0.001) \\
{[0.000]}\end{array}$ \\
\hline Inflation rate & $\begin{array}{r}30.110 \\
(0.001) \\
{[0.001]}\end{array}$ & $\begin{array}{r}30.825 \\
(0.001) \\
{[0.000]}\end{array}$ & $\begin{array}{r}28.886 \\
(0.002) \\
{[0.001]}\end{array}$ & $\begin{array}{r}26.172 \\
(0.005) \\
{[0.003]}\end{array}$ & $\begin{array}{r}30.412 \\
(0.002) \\
{[0.000]}\end{array}$ \\
\hline Government debt & $\begin{array}{l}1.382 \\
(0.014) \\
{[0.002]}\end{array}$ & $\begin{array}{l}1.587 \\
(0.007) \\
{[0.003]}\end{array}$ & $\begin{array}{l}1.313 \\
(0.025) \\
{[0.020]}\end{array}$ & $\begin{array}{l}1.561 \\
(0.007) \\
{[0.004]}\end{array}$ & $\begin{array}{l}1.389 \\
(0.016) \\
{[0.013]}\end{array}$ \\
\hline Past currency crisis & $\begin{array}{l}0.730 \\
(0.039) \\
{[0.061]}\end{array}$ & $\begin{array}{l}0.793 \\
(0.026) \\
{[0.036]}\end{array}$ & $\begin{array}{l}0.737 \\
(0.040) \\
{[0.061]}\end{array}$ & $\begin{array}{l}0.726 \\
(0.037) \\
{[0.061]}\end{array}$ & $\begin{array}{l}0.735 \\
(0.042) \\
{[0.055]}\end{array}$ \\
\hline EMU dummy & & $\begin{array}{r}-0.457 \\
(0.205) \\
{[0.156]}\end{array}$ & & & \\
\hline Inflation targeting dummy & & & $\begin{array}{r}-0.124 \\
(0.701) \\
{[0.682]}\end{array}$ & & \\
\hline Exchange rate peg dummy & & & & $\begin{array}{l}0.649 \\
(0.151) \\
{[0.146]}\end{array}$ & \\
\hline Floating exchange rate dummy & & & & & $\begin{array}{l}0.040 \\
(0.905) \\
{[0.898]}\end{array}$ \\
\hline$R^{2}$ & 0.494 & 0.515 & 0.495 & 0.521 & 0.494 \\
\hline Standard error & 0.930 & 0.922 & 0.941 & 0.916 & 0.942 \\
\hline
\end{tabular}

Numbers in parenthesis are $p$-values based on conventional standard errors, while numbers in brackets are $p$ values based on robust (White) standard errors. 
Table 6. Regression results for the duration of consumption contraction

\begin{tabular}{|c|c|c|c|c|c|}
\hline & $(1)$ & $(2)$ & $\begin{array}{c}\text { Specification } \\
\text { (3) }\end{array}$ & (4) & $(5)$ \\
\hline Constant & $\begin{array}{l}2.195 \\
(0.000) \\
{[0.000]}\end{array}$ & $\begin{array}{l}2.187 \\
(0.000) \\
{[0.000]}\end{array}$ & $\begin{array}{l}2.371 \\
(0.000) \\
{[0.000]}\end{array}$ & $\begin{array}{l}2.271 \\
(0.000) \\
{[0.000]}\end{array}$ & $\begin{array}{l}2.443 \\
(0.000) \\
{[0.000]}\end{array}$ \\
\hline Exchange rate variability & $\begin{array}{r}-20.742 \\
(0.022) \\
{[0.012]}\end{array}$ & $\begin{array}{r}-20.643 \\
(0.035) \\
{[0.017]}\end{array}$ & $\begin{array}{r}-16.695 \\
(0.074) \\
{[0.033]}\end{array}$ & $\begin{array}{r}-19.857 \\
(0.024) \\
{[0.018]}\end{array}$ & $\begin{array}{r}-15.916 \\
(0.093) \\
{[0.044]}\end{array}$ \\
\hline Inflation rate & $\begin{array}{r}46.381 \\
(0.000) \\
{[0.000]}\end{array}$ & $\begin{array}{r}46.391 \\
(0.000) \\
{[0.000]}\end{array}$ & $\begin{array}{r}43.983 \\
(0.000) \\
{[0.000]}\end{array}$ & $\begin{array}{r}37.925 \\
(0.001) \\
{[0.000]}\end{array}$ & $\begin{array}{r}42.350 \\
(0.000) \\
{[0.000]}\end{array}$ \\
\hline EMU dummy & & $\begin{array}{l}0.012 \\
(0.977) \\
{[0.977]}\end{array}$ & & & \\
\hline Inflation targeting dummy & & & $\begin{array}{r}-0.535 \\
(0.175) \\
{[0.127]}\end{array}$ & & \\
\hline Exchange rate peg dummy & & & & $\begin{array}{l}1.038 \\
(0.058) \\
{[0.017]}\end{array}$ & \\
\hline Floating exchange rate dummy & & & & & $\begin{array}{r}-0.547 \\
(0.168) \\
{[0.120]}\end{array}$ \\
\hline$R^{2}$ & 0.358 & 0.358 & 0.386 & 0.411 & 0.386 \\
\hline Standard error & 1.237 & 1.252 & 1.224 & 1.198 & 1.223 \\
\hline
\end{tabular}

Numbers in parenthesis are $p$-values based on conventional standard errors, while numbers in brackets are $p$ values based on robust (White) standard errors. 
Table 7. Probit estimates of the likelihood of a banking crisis

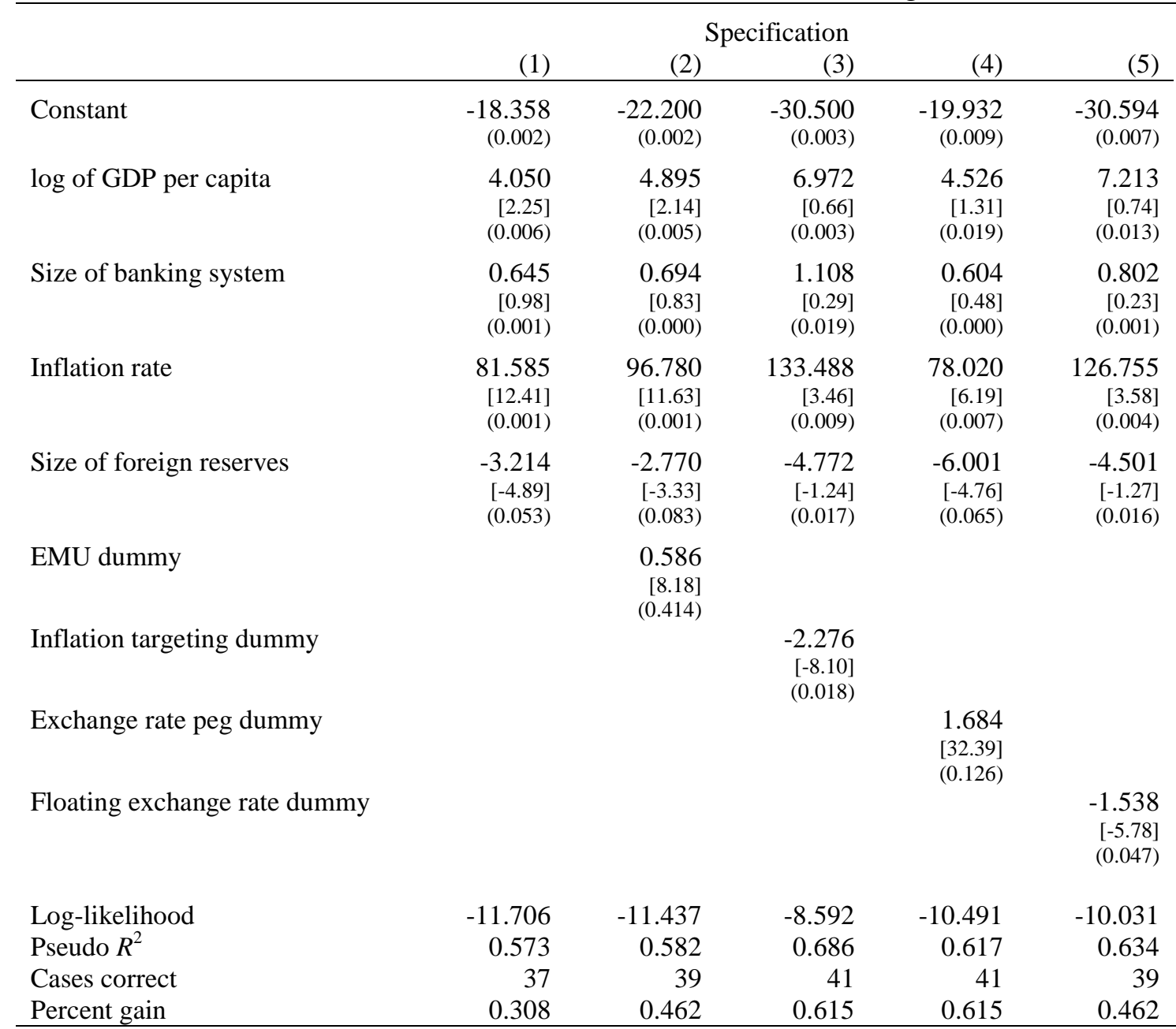

Numbers in brackets are marginal effects of a one-unit change in the explanatory variables on the probability of a banking crisis ( $\times 100$ to convert into percentages), evaluated at the mean of the data, except when reporting the marginal effects for the dummy variables, in which case the numbers are the effects of a change from 0 to 1 on the probability of a banking crisis. Numbers in parenthesis are $p$ values based on robust (Hubert-White) standard errors. Cases correct show the number of cases predicted correctly by each model, using a cut-off point of $50 \%$, while the percent gain shows the percent of incorrect cases predicted by a simple constant-probability specification corrected by each model. 
Table 8. Probit estimates of the likelihood of a currency crisis

\begin{tabular}{lrrr}
\hline & $\begin{array}{r}\text { Parameter } \\
\text { estimate }\end{array}$ & $\begin{array}{r}\text { Marginal } \\
\text { effect }\end{array}$ & $p$-value \\
\hline Constant & -20.558 & - & 0.004 \\
log of GDP per capita & 5.471 & $2.10 \mathrm{E}-7$ & 0.002 \\
Size of banking system & 1.040 & $1.10 \mathrm{E}-7$ & 0.005 \\
Exchange rate variability & 62.843 & $6.63 \mathrm{E}-7$ & 0.003 \\
Fiscal balances & -40.440 & $-4.27 \mathrm{E}-7$ & 0.005 \\
Central bank independence & -13.353 & $-1.41 \mathrm{E}-7$ & 0.016 \\
Past banking crisis & 7.402 & 0.89 & 0.003 \\
& & & \\
Log-likelihood & -3.075 & & \\
Pseudo $R^{2}$ & 0.626 & & \\
Cases correct & 45 & & \\
Percent gain & 0.500 & & \\
\hline
\end{tabular}

The table reports the marginal effects of a one-unit change in the explanatory variables on the probability of a currency crisis $(\times 100$ to convert into percentages), evaluated at the mean of the data, except when reporting the marginal effects for 'Past banking crisis', in which case the number is the effect of a change from 0 to 1 on the probability of a currency crisis. The $p$-values are based on robust (Hubert-White) standard errors. Cases correct show the number of cases predicted correctly by the model, using a cut-off point of $50 \%$, while the percent gain shows the percent of incorrect cases predicted by a simple constant-probability specification corrected by the model. 
Table 9. Probit estimates of the likelihood of a banking, currency or twin crisis

\begin{tabular}{|c|c|c|c|c|c|}
\hline & \multicolumn{4}{|c|}{ Specification } & \multirow[b]{2}{*}{$(5)$} \\
\hline & (1) & $(2)$ & (3) & (4) & \\
\hline log of GDP per capita & $\begin{array}{r}5.490 \\
{[4.38]} \\
(0.000)\end{array}$ & $\begin{array}{r}5.458 \\
{[4.40]} \\
(0.000)\end{array}$ & $\begin{array}{r}5.696 \\
{[4.22]} \\
(0.001)\end{array}$ & $\begin{array}{r}6.103 \\
{[4.12]} \\
(0.001)\end{array}$ & $\begin{array}{r}5.822 \\
{[4.21]} \\
(0.003)\end{array}$ \\
\hline Financial deepening & $\begin{array}{r}-0.471 \\
{[-1.03]} \\
(0.023)\end{array}$ & $\begin{array}{r}-0.463 \\
{[-1.02]} \\
(0.038)\end{array}$ & $\begin{array}{r}-0.556 \\
{[-1.14]} \\
(0.055)\end{array}$ & $\begin{array}{r}-0.633 \\
{[-1.17]} \\
(0.029)\end{array}$ & $\begin{array}{r}-0.558 \\
{[-1.11]} \\
(0.059)\end{array}$ \\
\hline Size of banking system & $\begin{array}{r}0.545 \\
{[1.19]} \\
(0.002)\end{array}$ & $\begin{array}{r}0.544 \\
{[1.20]} \\
(0.002)\end{array}$ & $\begin{array}{r}0.554 \\
{[1.13]} \\
(0.006)\end{array}$ & $\begin{array}{r}0.506 \\
{[0.94]} \\
(0.001)\end{array}$ & $\begin{array}{r}0.542 \\
{[1.07]} \\
(0.006)\end{array}$ \\
\hline Exchange rate variability & $\begin{array}{r}29.566 \\
{[6.47]} \\
(0.017)\end{array}$ & $\begin{array}{r}29.093 \\
{[6.43]} \\
(0.023)\end{array}$ & $\begin{array}{r}31.827 \\
{[6.47]} \\
(0.014)\end{array}$ & $\begin{array}{r}31.700 \\
{[5.87]} \\
(0.013)\end{array}$ & $\begin{array}{r}32.462 \\
{[6.44]} \\
(0.017)\end{array}$ \\
\hline Inflation rate & $\begin{array}{r}56.909 \\
{[12.45]} \\
(0.014)\end{array}$ & $\begin{array}{r}56.163 \\
{[12.41]} \\
(0.020)\end{array}$ & $\begin{array}{r}56.876 \\
{[11.54]} \\
(0.023)\end{array}$ & $\begin{array}{r}46.700 \\
{[8.65]} \\
(0.015)\end{array}$ & $\begin{array}{r}56.964 \\
{[11.29]} \\
(0.032)\end{array}$ \\
\hline Fiscal balances & $\begin{array}{r}-14.814 \\
{[-3.24]} \\
(0.010)\end{array}$ & $\begin{array}{r}-15.154 \\
{[-3.35]} \\
(0.006)\end{array}$ & $\begin{array}{r}-14.233 \\
{[-2.89]} \\
(0.010)\end{array}$ & $\begin{array}{r}-20.175 \\
{[-3.74]} \\
(0.008)\end{array}$ & $\begin{array}{r}-14.995 \\
{[-2.97]} \\
(0.010)\end{array}$ \\
\hline Threshold level 1 & $\begin{array}{r}22.633 \\
(0.000)\end{array}$ & $\begin{array}{r}22.447 \\
(0.000)\end{array}$ & $\begin{array}{r}23.188 \\
(0.001)\end{array}$ & $\begin{array}{r}24.449 \\
(0.000)\end{array}$ & $\begin{array}{r}23.560 \\
(0.002)\end{array}$ \\
\hline Threshold level 2 & $\begin{array}{r}27.539 \\
(0.000)\end{array}$ & $\begin{array}{r}27.319 \\
(0.000)\end{array}$ & $\begin{array}{r}28.100 \\
(0.001)\end{array}$ & $\begin{array}{r}28.860 \\
(0.000)\end{array}$ & $\begin{array}{r}28.515 \\
(0.002)\end{array}$ \\
\hline EMU dummy & & $\begin{array}{r}-0.097 \\
{[-2.11]} \\
(0.883)\end{array}$ & & & \\
\hline Inflation targeting dummy & & & $\begin{array}{r}-0.505 \\
{[-9.84]} \\
(0.495)\end{array}$ & & \\
\hline Exchange rate peg dummy & & & & $\begin{array}{c}1.291 \\
{[36.00]} \\
(0.151)\end{array}$ & \\
\hline Floating exchange rate dummy & & & & & $\begin{array}{r}-0.448 \\
{[-8.81]} \\
(0.527)\end{array}$ \\
\hline Log-likelihood & -14.185 & -14.176 & -13.831 & -13.294 & -13.907 \\
\hline Pseudo $R^{2}$ & 0.555 & 0.555 & 0.566 & 0.583 & 0.564 \\
\hline Cases correct & 39 & 39 & 40 & 41 & 40 \\
\hline Percent gain & 0.500 & 0.500 & 0.571 & 0.643 & 0.571 \\
\hline
\end{tabular}

Numbers in brackets are marginal effects of a one-unit change in the explanatory variables on the probability of a banking or a currency crisis ( $\times 100$ to convert into percentages), evaluated at the mean of the data, except when reporting the marginal effects for the dummy variables, in which case the numbers are the effects of a change from 0 to 1 on the probability of a banking or a crisis. The marginal effects on the probability of a twin crisis are extremely small and therefore not reported. The marginal effects on the probability of no crisis are therefore practically the same as the marginal effects on the probability of either banking or currency crisis, but with reversed signs. Numbers in parenthesis are $p$-values based on robust (Hubert-White) standard errors. Cases correct show the number of cases predicted correctly by each model, using a cut-off point of 50\%, while the percent gain shows the percent of incorrect cases predicted by a simple constant-probability specification corrected by each model. 
Table 10. Robustness analysis: adding different country group dummies

\begin{tabular}{|c|c|c|c|c|c|c|}
\hline & $\begin{array}{r}\text { Output } \\
\text { loss } \\
\text { equation } \\
\end{array}$ & $\begin{array}{r}\text { Consump- } \\
\text { tion loss } \\
\text { equation } \\
\end{array}$ & $\begin{array}{r}\text { Output } \\
\text { duration } \\
\text { equation }\end{array}$ & $\begin{array}{r}\text { Consump- } \\
\text { tion duration } \\
\text { equation } \\
\end{array}$ & $\begin{array}{r}\text { Banking } \\
\text { crisis } \\
\text { equation } \\
\end{array}$ & $\begin{array}{r}\text { Twin } \\
\text { crisis } \\
\text { equation } \\
\end{array}$ \\
\hline OECD & $\begin{array}{r}-0.025 \\
(0.167)\end{array}$ & $\begin{array}{r}-0.014 \\
(0.261)\end{array}$ & $\begin{array}{r}-0.548 \\
(0.165)\end{array}$ & $\begin{array}{r}-0.360 \\
(0.230)\end{array}$ & $\begin{array}{l}1.125 \\
(0.390)\end{array}$ & $\begin{array}{l}0.164 \\
(0.834)\end{array}$ \\
\hline $\mathrm{EU}$ & $\begin{array}{r}-0.003 \\
(0.848)\end{array}$ & $\begin{array}{l}0.015 \\
(0.107)\end{array}$ & $\begin{array}{l}0.078 \\
(0.834)\end{array}$ & $\begin{array}{l}0.037 \\
(0.911)\end{array}$ & $\begin{array}{r}-0.160 \\
(0.801)\end{array}$ & $\begin{array}{r}-0.550 \\
(0.402)\end{array}$ \\
\hline EME & $\begin{array}{r}-0.013 \\
(0.452)\end{array}$ & $\begin{array}{r}-0.004 \\
(0.727)\end{array}$ & $\begin{array}{l}0.074 \\
(0.868)\end{array}$ & $\begin{array}{l}0.067 \\
(0.864)\end{array}$ & $\begin{array}{r}-5.912 \\
(0.067)\end{array}$ & $\begin{array}{r}-6.796 \\
(0.103)\end{array}$ \\
\hline CEA & $\begin{array}{l}0.046 \\
(0.118)\end{array}$ & $\begin{array}{l}0.011 \\
(0.477)\end{array}$ & $\begin{array}{l}0.235 \\
(0.678)\end{array}$ & $\begin{array}{r}-0.179 \\
(0.706)\end{array}$ & $\begin{array}{r}-3.657 \\
(0.069)\end{array}$ & $\begin{array}{r}-0.778 \\
(0.382)\end{array}$ \\
\hline VSOE & $\begin{array}{l}0.042 \\
(0.190)\end{array}$ & $\begin{array}{l}0.026 \\
(0.060)\end{array}$ & $\begin{array}{l}0.000 \\
(0.976)\end{array}$ & $\begin{array}{l}0.286 \\
(0.467)\end{array}$ & $\begin{array}{r}-4.014 \\
(0.006)\end{array}$ & $\begin{array}{l}0.525 \\
(0.431)\end{array}$ \\
\hline High income countries & $\begin{array}{r}-0.011 \\
(0.216)\end{array}$ & $\begin{array}{r}-0.000 \\
(0.985)\end{array}$ & $\begin{array}{r}-0.467 \\
(0.181)\end{array}$ & $\begin{array}{r}-0.584 \\
(0.181)\end{array}$ & $\begin{array}{r}-0.797 \\
(0.317)\end{array}$ & $\begin{array}{r}-2.093 \\
(0.031)\end{array}$ \\
\hline Mid-income countries & $\begin{array}{l}0.013 \\
(0.204)\end{array}$ & $\begin{array}{r}-0.004 \\
(0.809)\end{array}$ & $\begin{array}{l}0.361 \\
(0.290)\end{array}$ & $\begin{array}{l}0.350 \\
(0.360)\end{array}$ & $\begin{array}{r}-0.129 \\
(0.833)\end{array}$ & $\begin{array}{l}1.092 \\
(0.197)\end{array}$ \\
\hline Low income countries & $\begin{array}{r}-0.011 \\
(0.611)\end{array}$ & $\begin{array}{l}0.007 \\
(0.772)\end{array}$ & $\begin{array}{l}0.016 \\
(0.976)\end{array}$ & $\begin{array}{l}0.313 \\
(0.581)\end{array}$ & $\begin{array}{l}3.151 \\
(0.009)\end{array}$ & $\begin{array}{l}1.229 \\
(0.425)\end{array}$ \\
\hline Large countries & $\begin{array}{l}0.016 \\
(0.145)\end{array}$ & $\begin{array}{l}0.008 \\
(0.661)\end{array}$ & $\begin{array}{l}0.239 \\
(0.584)\end{array}$ & $\begin{array}{l}0.164 \\
(0.721)\end{array}$ & $\begin{array}{l}1.596 \\
(0.045)\end{array}$ & $\begin{array}{l}1.249 \\
(0.041)\end{array}$ \\
\hline Mid-sized countries & $\begin{array}{r}-0.027 \\
(0.008)\end{array}$ & $\begin{array}{r}-0.030 \\
(0.027)\end{array}$ & $\begin{array}{c}-0.298 \\
(0.388)\end{array}$ & $\begin{array}{r}-0.475 \\
(0.204)\end{array}$ & $\begin{array}{r}-0.926 \\
(0.174)\end{array}$ & $\begin{array}{r}-0.928 \\
(0.124)\end{array}$ \\
\hline Small countries & $\begin{array}{l}0.025 \\
(0.011)\end{array}$ & $\begin{array}{l}0.043 \\
(0.043)\end{array}$ & $\begin{array}{l}0.248 \\
(0.543)\end{array}$ & $\begin{array}{l}0.486 \\
(0.173)\end{array}$ & $\begin{array}{r}-1.152 \\
(0.231)\end{array}$ & $\begin{array}{r}-0.317 \\
(0.621)\end{array}$ \\
\hline Africa & $\begin{array}{r}-0.052 \\
(0.000)\end{array}$ & $\begin{array}{r}-0.065 \\
(0.011)\end{array}$ & $\begin{array}{r}-0.850 \\
(0.000)\end{array}$ & $\begin{array}{l}1.163 \\
(0.000)\end{array}$ & - & $\begin{array}{r}-3.330 \\
(0.005)\end{array}$ \\
\hline Asia & $\begin{array}{l}0.006 \\
(0.789)\end{array}$ & $\begin{array}{l}0.022 \\
(0.165)\end{array}$ & $\begin{array}{r}-0.152 \\
(0.777)\end{array}$ & $\begin{array}{l}0.258 \\
(0.598)\end{array}$ & - & $\begin{array}{l}3.427 \\
(0.024)\end{array}$ \\
\hline Europe & $\begin{array}{l}0.010 \\
(0.374)\end{array}$ & $\begin{array}{l}0.005 \\
(0.736)\end{array}$ & $\begin{array}{l}0.146 \\
(0.697)\end{array}$ & $\begin{array}{l}0.000 \\
(0.999)\end{array}$ & $\begin{array}{r}-0.010 \\
(0.990)\end{array}$ & $\begin{array}{r}-0.548 \\
(0.519)\end{array}$ \\
\hline Latin America & $\begin{array}{r}-0.018 \\
(0.249)\end{array}$ & $\begin{array}{r}-0.028 \\
(0.542)\end{array}$ & $\begin{array}{l}0.453 \\
(0.142)\end{array}$ & $\begin{array}{l}0.442 \\
(0.522)\end{array}$ & - & $\begin{array}{r}-4.191 \\
(0.001)\end{array}$ \\
\hline North America & $\begin{array}{r}-0.001 \\
(0.953)\end{array}$ & $\begin{array}{r}-0.003 \\
(0.872)\end{array}$ & $\begin{array}{r}-0.136 \\
(0.774)\end{array}$ & $\begin{array}{r}-0.383 \\
(0.217)\end{array}$ & $\begin{array}{l}0.745 \\
(0.441)\end{array}$ & $\begin{array}{r}-0.610 \\
(0.464)\end{array}$ \\
\hline Oceania & $\begin{array}{r}-0.012 \\
(0.434)\end{array}$ & $\begin{array}{r}-0.011 \\
(0.617)\end{array}$ & $\begin{array}{r}-0.232 \\
(0.864)\end{array}$ & $\begin{array}{r}-1.210 \\
(0.296)\end{array}$ & - & $\begin{array}{r}-7.567 \\
(0.000)\end{array}$ \\
\hline
\end{tabular}

The table reports estimated parameters for country group dummy variables in each equation from Specification 1 in Tables 3-9, except for the probit model for currency crisis, where identification problems made it impossible to add country group dummies to the model specification. The country groups are explained in Table 2. 'High income countries' represents the upper GDP per capita quartile of the country sample, 'Mid-income countries' represents the two mid GDP per capita quartiles of the country sample, while 'Low income countries' represents the low GDP per capita quartile of the country sample. Different size groups are defined identically. Numbers in parenthesis are $p$-values based on robust standard errors. 
Output loss

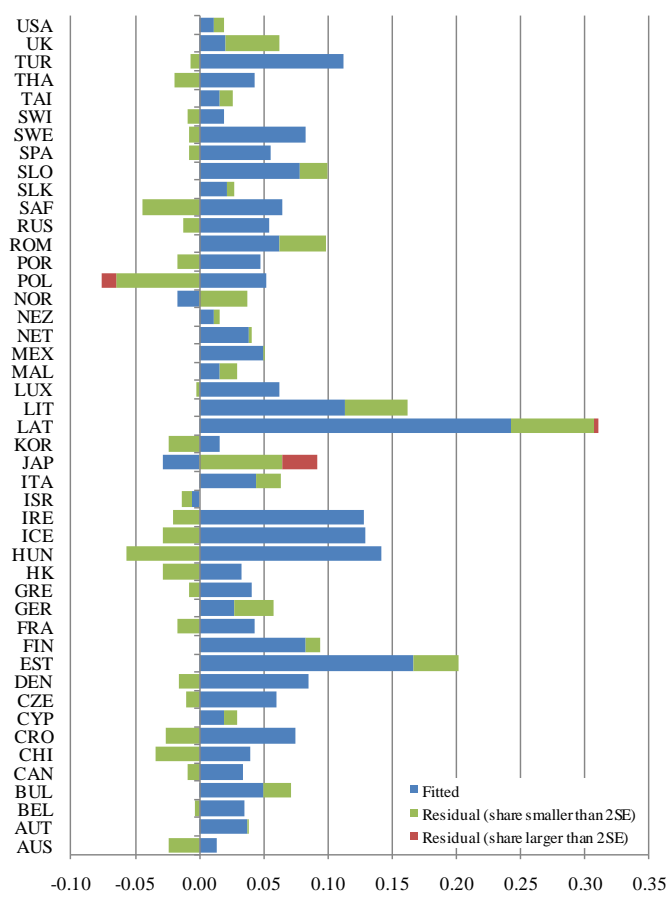

Consumption loss

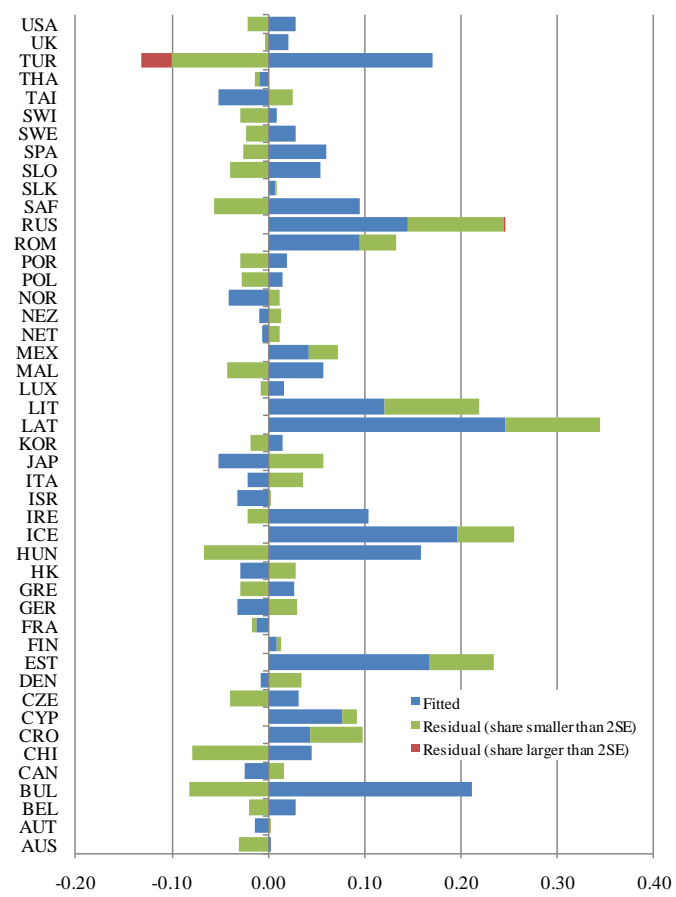

Figure 1. Actual and fitted output and consumption contraction (Specification 1 in Tables 3 and 4)

Output duration

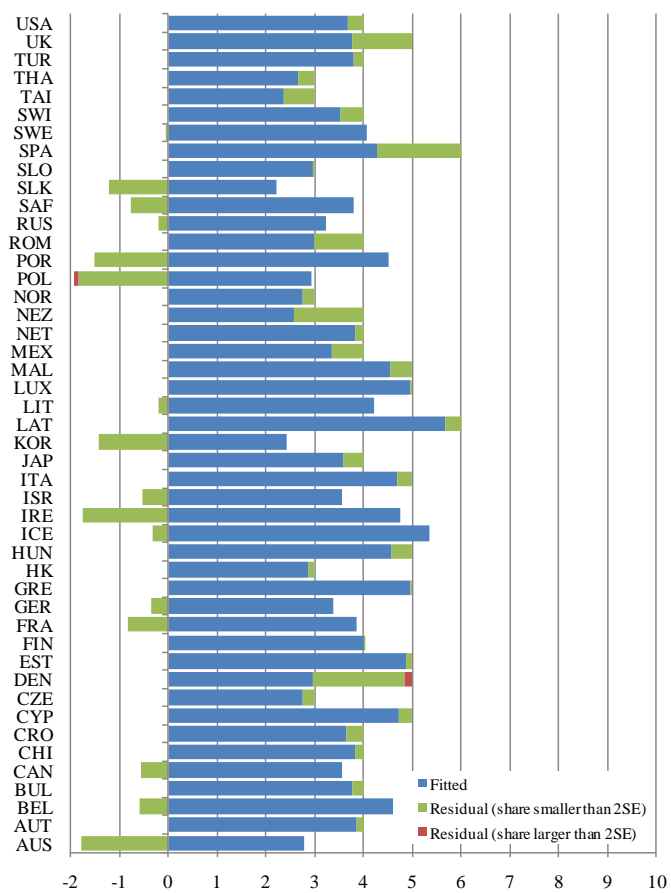

Consumption duration

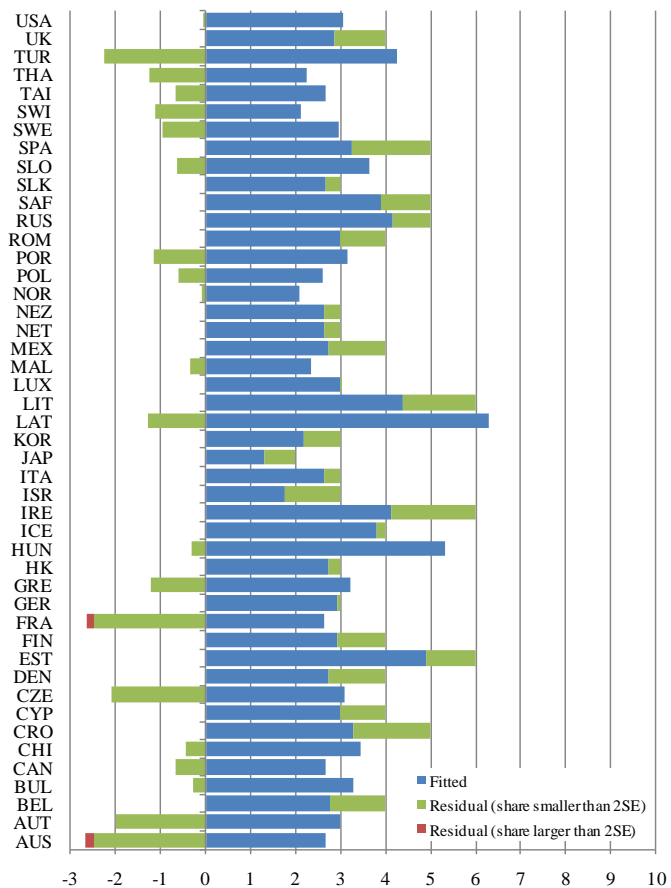

Figure 2. Actual and fitted output and consumption contraction duration (Specification 1 in Tables 5 and 6) 
Probability of a banking crisis

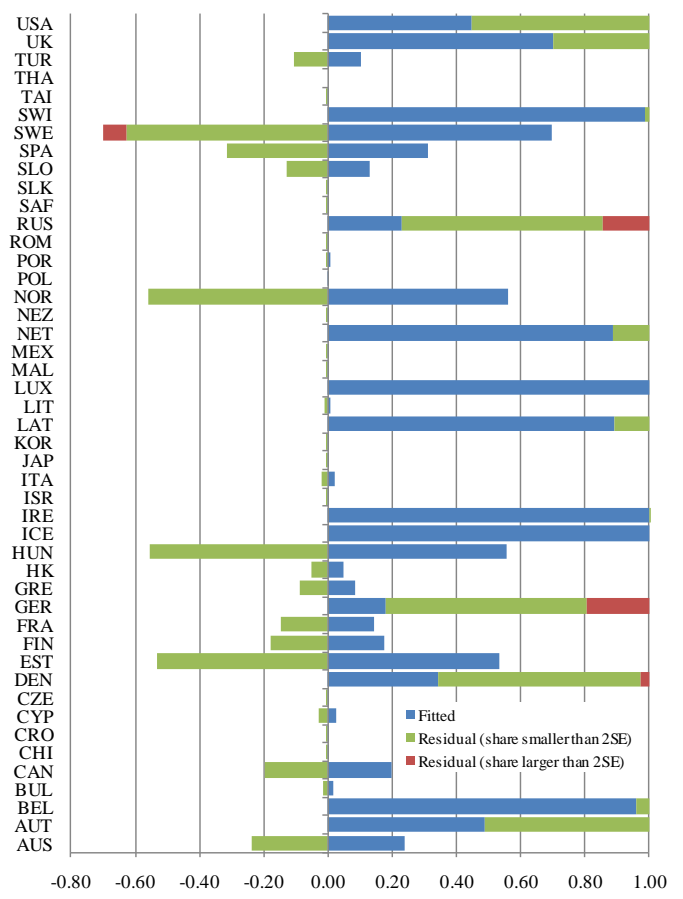

Probability of a currency crisis

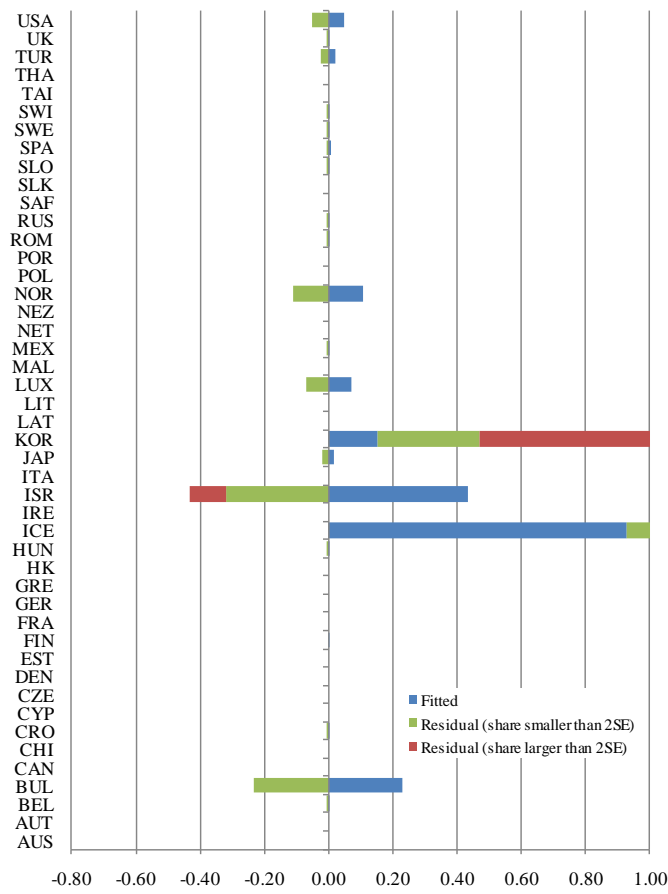

Figure 3. Actual and fitted banking and currency crisis (Specification 1 in Tables 7 and 8)

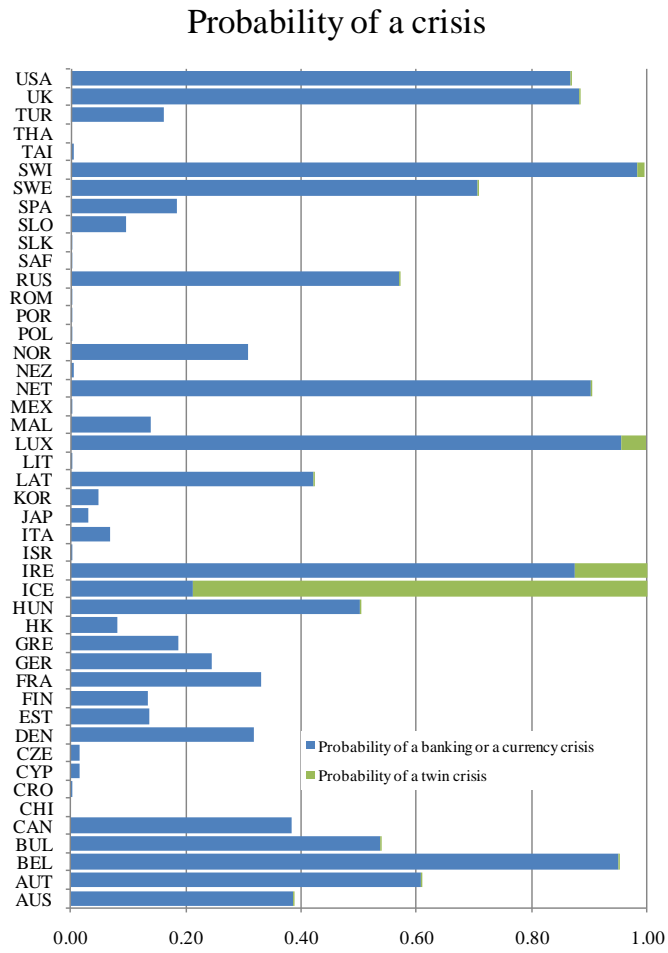

Figure 4. Actual and fitted banking and currency crisis (Specification 1 in Table 9) 
Output loss

Deviations from sample average and main contributors

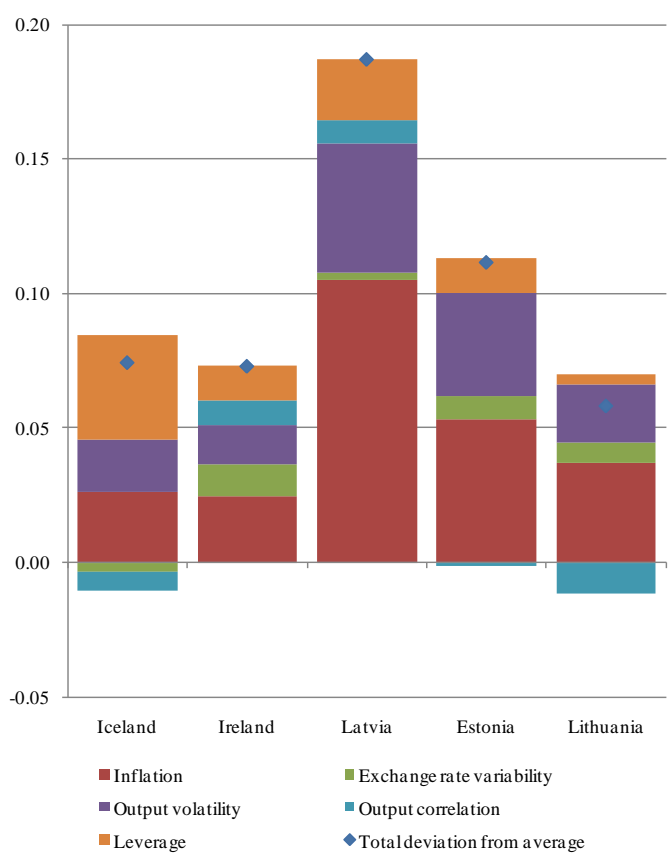

Output duration

Deviations from sample average and main contributors

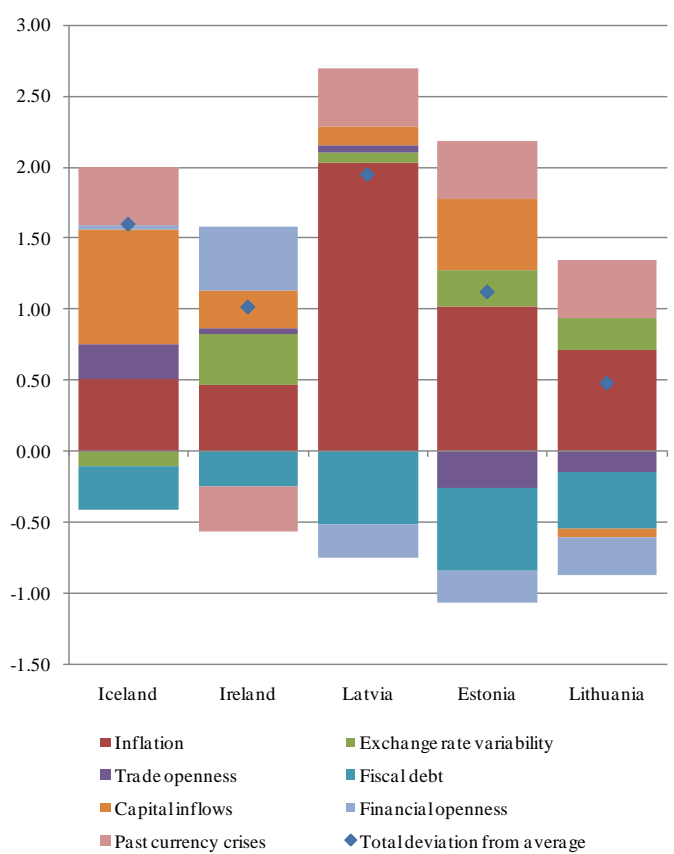

Consumption loss

Deviations from sample average and main contributors

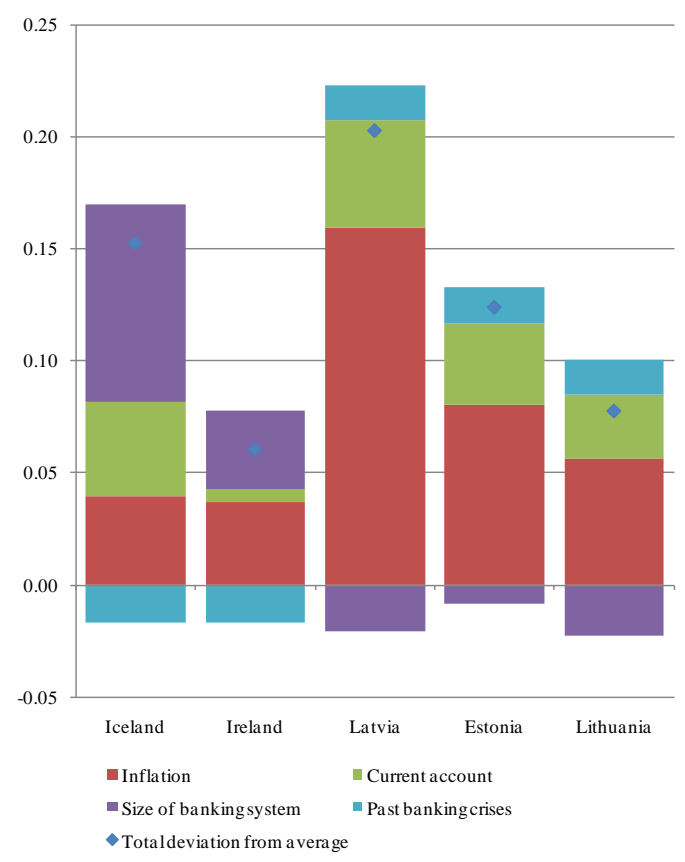

Consumption duration

Deviations from sample average and main contributors

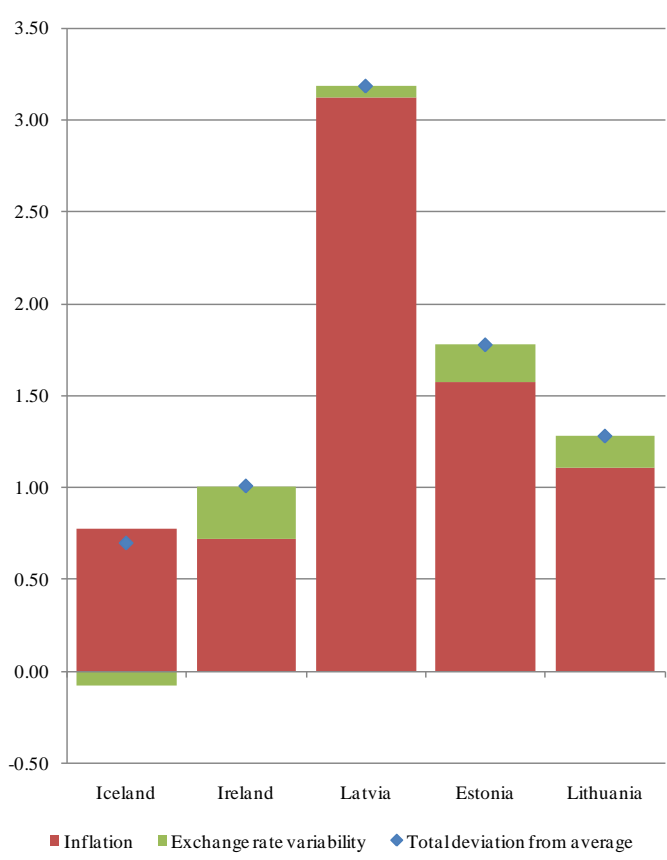

Figure 5. Baseline predictions of output and consumption losses and duration in selected countries (Contributions of explanatory variables to deviations from sample averages) 


\section{Appendix: The data}

Table A1. Data definitions and sources

\begin{tabular}{|c|c|c|}
\hline Variable & Description & Source \\
\hline $\begin{array}{l}\text { Depth of output } \\
\text { contraction }\end{array}$ & $\begin{array}{l}\text { Dependent variables } \\
\text { Log difference of seasonally adjusted GDP } \\
\text { level from peak in 2007Q1-2008Q4 to } \\
\text { 2009Q4 }\end{array}$ & $\begin{array}{l}\text { Eurostat, Reuters/EcoWin, local } \\
\text { central banks and Global } \\
\text { Insight }\end{array}$ \\
\hline $\begin{array}{l}\text { Depth of consumption } \\
\text { contraction }\end{array}$ & $\begin{array}{l}\text { Log difference of seasonally adjusted private } \\
\text { consumption level from peak in 2007Q1- } \\
\text { 2008Q4 to 2009Q4 }\end{array}$ & $\begin{array}{l}\text { Eurostat, Reuters/EcoWin, local } \\
\text { central banks and Global } \\
\text { Insight }\end{array}$ \\
\hline $\begin{array}{l}\text { Duration of output } \\
\text { contraction }\end{array}$ & $\begin{array}{l}\text { Numbers of quarters with negative quarter-on- } \\
\text { quarter growth in seasonally adjusted GDP } \\
\text { from 2008Q3 to 2009Q4 }\end{array}$ & $\begin{array}{l}\text { Eurostat, Reuters/EcoWin, local } \\
\text { central banks and Global } \\
\text { Insight }\end{array}$ \\
\hline $\begin{array}{l}\text { Duration of } \\
\text { consumption } \\
\text { contraction }\end{array}$ & $\begin{array}{l}\text { Numbers of quarters with negative quarter-on- } \\
\text { quarter growth in seasonally adjusted private } \\
\text { consumption from } 2008 \mathrm{Q} 3 \text { to } 2009 \mathrm{Q} 4\end{array}$ & $\begin{array}{l}\text { Eurostat, Reuters/EcoWin, local } \\
\text { central banks and Global } \\
\text { Insight }\end{array}$ \\
\hline Banking crisis & $\begin{array}{l}\text { Indicator variable for a systemic banking } \\
\text { crisis: defined as } 1 \text { if a country's corporate } \\
\text { and financial sectors experience a large } \\
\text { number of defaults and financial institutions } \\
\text { and corporations face great difficulties } \\
\text { repaying contracts on time leading to a rise in } \\
\text { non-performing loans and an almost complete } \\
\text { exhaustion of aggregate banking system } \\
\text { capital and } 0 \text { otherwise }\end{array}$ & $\begin{array}{l}\text { Laeven and Valencia (2008) } \\
\text { updated database and authors } \\
\text { own elaboration }\end{array}$ \\
\hline Currency crisis & $\begin{array}{l}\text { Indicator variable for a currency crisis: } \\
\text { defined as } 1 \text { if the annual average of the } \\
\text { nominal effective exchange rate depreciated } \\
\text { by } 30 \% \text { or more in } 2008-2009 \text { and if this } \\
\text { depreciation is also at least a } 10 \text { percentage } \\
\text { points increase in the rate of depreciation } \\
\text { compared to the two year period before and } 0 \\
\text { otherwise }\end{array}$ & $\begin{array}{l}\text { Effective exchange rates from } \\
\text { the BIS database }\end{array}$ \\
\hline GDP level & $\begin{array}{c}\text { Economic structure } \\
\text { GDP level in 2008 (PPP adjusted billion US\$) }\end{array}$ & $\begin{array}{l}\text { CIA World Factbook } \\
\text { (www.cia.gov/publications/fact } \\
\underline{\text { book) }}\end{array}$ \\
\hline GDP per capita & $\begin{array}{l}\text { GDP per capita in } 2008 \text { (PPP adjusted } \\
\text { thousand US\$) }\end{array}$ & $\begin{array}{l}\text { CIA World Factbook } \\
\text { (www.cia.gov/publications/fact } \\
\underline{\text { book) }}\end{array}$ \\
\hline
\end{tabular}


Table A1. Data definitions and sources (cont.)

\begin{tabular}{|c|c|c|}
\hline Variable & Description & Source \\
\hline Financial deepening & $\begin{array}{l}\text { Financial structure and development } \\
\text { Broad money (M2) as a share of GDP in } 2007\end{array}$ & $\begin{array}{l}\text { IMF/IFS and local central } \\
\text { banks }\end{array}$ \\
\hline Size of banking system & $\begin{array}{l}\text { Total assets of the } 5 \text { largest banks in each } \\
\text { country as a share of GDP in } 2007\end{array}$ & The Banker (2008) database \\
\hline $\begin{array}{l}\text { Stock market } \\
\text { capitalisation }\end{array}$ & $\begin{array}{l}\text { Market value of publicly traded stocks as a } \\
\text { share of GDP in } 2007\end{array}$ & $\begin{array}{l}\text { CIA World Factbook } \\
\text { (www.cia.gov/publications/fact } \\
\underline{\text { book) }}\end{array}$ \\
\hline Trade openness & $\begin{array}{c}\text { International real linkages } \\
\text { Imports and exports as a share of GDP in } 2007\end{array}$ & IMF/IFS \\
\hline Output correlation & $\begin{array}{l}\text { Correlation of cyclical part of seasonally } \\
\text { adjusted domestic GDP and world output } \\
\text { 1985Q1-2007Q4 (or time period available, } \\
\text { using the HP filter to generate trend GDP. For } \\
\text { France, Germany, Italy, Japan, UK, and the } \\
\text { US world output is measured using world } \\
\text { output excluding each of these countries }\end{array}$ & $\begin{array}{l}\text { Eurostat, Reuters/EcoWin, local } \\
\text { central banks and Pétursson } \\
(2010)\end{array}$ \\
\hline $\begin{array}{l}\text { Manufacturing exports } \\
\text { share }\end{array}$ & $\begin{array}{l}\text { Share of manufacturing exports (SITC } 5 \text { to } 8 \text {, } \\
\text { less } 667 \text { and 68) in total merchandise exports } \\
\text { in } 2006\end{array}$ & $\begin{array}{l}\text { UN/UNCTAD database } \\
\text { (www.unctad.org/Handbook) }\end{array}$ \\
\hline Trade diversification & $\begin{array}{l}\text { A modified Finger-Kreinen index of trade } \\
\text { similarities, measuring to what extent a } \\
\text { country's trade structure in } 2006 \text { differs from } \\
\text { that of the average country. Index ranging } \\
\text { from } 0 \text { to } 1 \text {, with higher numbers indicating a } \\
\text { bigger difference from the world average }\end{array}$ & $\begin{array}{l}\text { UN/UNCTAD database } \\
\text { (www.unctad.org/Handbook) }\end{array}$ \\
\hline Trade concentration & $\begin{array}{l}\text { A Herfindahl-Hirschmann index measuring } \\
\text { the degree of market concentration in } \\
\text { country's trade in } 2006 \text {. Index ranging from } 0 \\
\text { to } 1 \text {, with higher numbers indicating greater } \\
\text { market concentration in trade }\end{array}$ & $\begin{array}{l}\text { UN/UNCTAD database } \\
\text { (www.unctad.org/Handbook) }\end{array}$ \\
\hline Financial openness & $\begin{array}{l}\text { International financial linkages } \\
\text { Sum of foreign assets and liabilities as a share } \\
\text { of GDP in } 2007\end{array}$ & $\begin{array}{l}\text { Lane and Milesi-Ferretti } \\
\text { (2006); updated database }\end{array}$ \\
\hline Capital inflows & FDI inward flows as share of GDP in 2007 & $\begin{array}{l}\text { UN/UNCTAD database } \\
\text { (www.unctad.org/Handbook) }\end{array}$ \\
\hline $\begin{array}{l}\text { Access to US\$ } \\
\text { liquidity }\end{array}$ & $\begin{array}{l}\text { Indicator variable for participation in the US } \\
\text { Fed liquidity program in 2008: defined as } 1 \text { if } \\
\text { a country participated in the liquidity program } \\
\text { and } 0 \text { otherwise }\end{array}$ & McGuire and von Peter (2009) \\
\hline
\end{tabular}


Table A1. Data definitions and sources (cont.)

\begin{tabular}{|c|c|c|}
\hline Variable & Description & Source \\
\hline Output volatility & $\begin{array}{l}\text { Underlying economic volatility } \\
\text { Standard deviation of cyclical component of } \\
\text { seasonally adjusted GDP in 1985Q1-2007Q4 } \\
\text { (or time period available, using the HP filter to } \\
\text { generate trend GDP }\end{array}$ & $\begin{array}{l}\text { Eurostat, Reuters/EcoWin and } \\
\text { local central banks }\end{array}$ \\
\hline $\begin{array}{l}\text { Exchange rate } \\
\text { variability }\end{array}$ & $\begin{array}{l}\text { Standard deviation of quarterly changes in } \\
\text { effective nominal exchange rates in 1994- } \\
2007\end{array}$ & $\begin{array}{l}\text { Effective exchange rates from } \\
\text { the BIS database }\end{array}$ \\
\hline Exchange rate noise & $\begin{array}{l}\text { A measure of the standard deviation of the } \\
\text { exchange rate risk premium, i.e. the present } \\
\text { value of the rational expectations deviation } \\
\text { from the uncovered interest rate parity } \\
\text { condition in effective exchange rates. } \\
\text { Estimated for the period 1990Q1-2005Q4 and } \\
\text { available for all the countries except, Bulgaria, } \\
\text { Croatia, Romania and Russia. }\end{array}$ & Pétursson (2010) \\
\hline \multicolumn{3}{|c|}{ Economic imbalances and vulnerabilities } \\
\hline Inflation rate & Average consumer price inflation in 2007 & $\begin{array}{l}\text { Eurostat, Reuters/EcoWin and } \\
\text { local central banks }\end{array}$ \\
\hline $\begin{array}{l}\text { Current account } \\
\text { balance }\end{array}$ & $\begin{array}{l}\text { Current account balance as a share of GDP in } \\
2007\end{array}$ & IMF/IFS \\
\hline $\begin{array}{l}\text { Size of foreign } \\
\text { reserves }\end{array}$ & Foreign reserves as a share of GDP in 2007 & IMF/IFS \\
\hline Financial leverage & $\begin{array}{l}\text { Ratio of domestic credit to domestic deposits } \\
\text { in } 2007\end{array}$ & IMF/IFS \\
\hline Fiscal balance & $\begin{array}{l}\text { General government balance as a share of } \\
\text { GDP in } 2007\end{array}$ & $\begin{array}{l}\text { IMF/IFS, Eurostat, } \\
\text { Reuters/EcoWin, local central } \\
\text { banks and statistical offices }\end{array}$ \\
\hline Government debt & $\begin{array}{l}\text { General government debt as a share of GDP in } \\
2007\end{array}$ & $\begin{array}{l}\text { IMF/IFS, Eurostat, } \\
\text { Reuters/EcoWin, local central } \\
\text { banks and statistical offices }\end{array}$ \\
\hline
\end{tabular}


Table A1. Data definitions and sources (cont.)

\begin{tabular}{|c|c|c|}
\hline Variable & Description & Source \\
\hline $\begin{array}{l}\text { Government } \\
\text { effectiveness }\end{array}$ & $\begin{array}{l}\text { Institutional factors } \\
\text { A measure of government governance quality. } \\
\text { Index from } 2007 \text { ranging from }-2.5 \text { to } 2.5 \text {, } \\
\text { with higher values indicating more effective } \\
\text { governments }\end{array}$ & $\begin{array}{l}\text { World Bank database } \\
\text { (http://info.worldbank.org/gove } \\
\underline{\text { rnance/wgi/index.asp) }}\end{array}$ \\
\hline Regulatory quality & $\begin{array}{l}\text { A measure of regulatory quality. Index from } \\
2007 \text { ranging from }-2.5 \text { to } 2.5 \text {, with higher } \\
\text { values indicating greater regulatory quality }\end{array}$ & $\begin{array}{l}\text { World Bank database } \\
\text { (http://info.worldbank.org/gove } \\
\underline{\text { rnance/wgi/index.asp) }}\end{array}$ \\
\hline $\begin{array}{l}\text { Legal structure and } \\
\text { security of property } \\
\text { rights }\end{array}$ & $\begin{array}{l}\text { A measure of quality of legal system covering } \\
\text { judicial independence, impartiality of courts, } \\
\text { protection of property rights, military } \\
\text { interference in rule of law, integrity of legal } \\
\text { system, legal enforcement of contracts and } \\
\text { restrictions on sale of real property. Index } \\
\text { from } 2006 \text {, ranging from } 0 \text { to } 10 \text {, with higher } \\
\text { values indicating greater quality of legal } \\
\text { system }\end{array}$ & $\begin{array}{l}\text { Economic Freedom Network } \\
\text { (http://www.freetheworld.com/ } \\
\underline{\text { 2008/2008Dataset.xls) }}\end{array}$ \\
\hline $\begin{array}{l}\text { Central bank } \\
\text { independence }\end{array}$ & $\begin{array}{l}\text { A measure of central bank overall } \\
\text { independence. Index ranging from } 0 \text { to } 1 \text {, with } \\
\text { higher values indicating greater independence }\end{array}$ & Fry et al. (2000) \\
\hline $\begin{array}{l}\text { Credit market } \\
\text { regulations }\end{array}$ & $\begin{array}{l}\text { A measure of regulatory burden in the } \\
\text { domestic credit market. Index from } 2006 \\
\text { ranging from } 0 \text { to } 10, \text { with lower values } \\
\text { indicating greater regulatory burden }\end{array}$ & $\begin{array}{l}\text { Fraser Institute database on } \\
\text { economic freedom } \\
\text { (http://www.freetheworld.com/ } \\
\text { 2008/2008Dataset.xls) }\end{array}$ \\
\hline $\begin{array}{l}\text { Labour market } \\
\text { regulations }\end{array}$ & $\begin{array}{l}\text { A measure of regulatory burden in the } \\
\text { domestic labour market. Index from } 2006 \\
\text { ranging from } 0 \text { to } 10 \text {, with lower values } \\
\text { indicating greater regulatory burden }\end{array}$ & $\begin{array}{l}\text { Fraser Institute database on } \\
\text { economic freedom } \\
\text { (http://www.freetheworld.com/ } \\
\text { 2008/2008Dataset.xls) }\end{array}$ \\
\hline Business regulations & $\begin{array}{l}\text { A measure of regulatory burden in general } \\
\text { business activities. Index from } 2006 \text { ranging } \\
\text { from } 0 \text { to } 10, \text { with lower values indicating } \\
\text { greater regulatory burden }\end{array}$ & $\begin{array}{l}\text { Fraser Institute database on } \\
\text { economic freedom } \\
\text { (http://www.freetheworld.com/ } \\
\text { 2008/2008Dataset.xls) }\end{array}$ \\
\hline $\begin{array}{l}\text { Economic freedom } \\
\text { index }\end{array}$ & $\begin{array}{l}\text { Overall economic freedom index, weighing } \\
\text { together sub-indices covering size of } \\
\text { government, legal structure, access to sound } \\
\text { money, freedom of international trade, and } \\
\text { regulation of markets. Index from } 2006 \\
\text { ranging from } 0 \text { to } 10 \text {, with higher values } \\
\text { indicating greater economic freedom }\end{array}$ & $\begin{array}{l}\text { Fraser Institute database on } \\
\text { economic freedom } \\
\text { (http://www.freetheworld.com/ } \\
\text { 2008/2008Dataset.xls) }\end{array}$ \\
\hline Past banking crisis & $\begin{array}{l}\text { Indicator variable for past banking crisis: } \\
\text { defined as } 1 \text { if it has experienced a banking } \\
\text { crisis in the past } 30 \text { years and } 0 \text { otherwise }\end{array}$ & Laeven and Valencia (2008) \\
\hline Past currency crisis & $\begin{array}{l}\text { Indicator variable for past currency crisis: } \\
\text { defined as } 1 \text { if it has experienced a banking } \\
\text { crisis in the past } 30 \text { years and } 0 \text { otherwise }\end{array}$ & Laeven and Valencia (2008) \\
\hline
\end{tabular}




\section{References}

Acemoglu, D., S. Johnson, J. Robinson and Y. Thaicharoen (2003). Institutional causes, macroeconomic symptoms: Volatility, crises and growth. Journal of Monetary Economics, 50, 49-123.

Allen, W. A., and R. Moessner (2010). Central bank co-operation and international liquidity in the financial crisis of 2008-9. BIS Working Papers, no. 310.

Barajas, A., G. Dell'Ariccia and A. Levchenko (2009). Credit booms: The good, the bad, and the ugly. Unpublished manuscript.

Barro, R. J., and J. F. Ursúa (2008). Macroeconomic crises since 1870. NBER Working Paper Series, no. 13940.

Berkmen, P., G. Gelos, R. Rennhack and J. P. Walsh (2009). The global financial crisis: Explaining cross-country differences in the output impact. IMF Working Paper, $\mathrm{WP} / 09 / 280$.

Blanchard, O., G. Dell'Ariccia, and P. Mauro (2010). Rethinking macroeconomic policy. IMF Staff Position Notes, SPN/10/03.

Bordo, M., B. Eichengreen, D. Klingebiel, and M. S. Martinez-Peria (2001). Is the crisis problem growing more severe? Economic Policy, 32, 51-82.

Buiter, W. H., and A. Sibert (2008). The Icelandic banking crisis and what to do about it: The lender of last resort theory of optimal currency areas. CEPR Policy Insight no. 26.

Carvalho Filho, I., (2010). Inflation targeting and the crisis: An empirical assessment. IMF Working Paper, WP/10/45.

Cecchetti, S. G., M. Kohler, and C. Upper (2009). Financial crisis and economic activity. NBER Working Paper Series, no. 15379.

Claessens, S., M. A. Kose, and M. E. Terrones (2009). What happens during recessions, crunches and busts? Economic Policy, 60, 267-293.

Claessens, S., G. Dell'Ariccia, D. Igan and L. Laeven (2010). Cross-country experiences and policy implications from the global financial crisis. Economic Policy, 61, 267-293.

Coulibaly, B., (2009). Currency unions and currency crises: An empirical assessment. International Journal of Finance and Economics, 14, 199-221.

Davis, E. P., (2008). Liquidity, financial crises and the lender of last resort - How much of a departure is the sub-prime crisis? In Lessons from the Financial Turmoil of 2007 and 2008, P. Bloxham and C. Kent (eds.). Reserve Bank of Australia.

Dell'Ariccia, G., E. Detragiache and R. Rajan (2008). The real effects of banking crises. Journal of Financial Intermediation, 17, 89-112.

Demirguc-Kunt, A., and L. Serven (2009). Are the sacred cows dead? Implications of the financial crisis for macro and financial policies. World Bank Policy Research Working Paper no. 4807.

Dooley, M., E. Fernandez-Arias and K. Kletzer (1994). Recent private capital inflows to developing countries: Is the debt crisis history? NBER Working Paper Series, no. 4792 . 
Forbes, K. J., and M. D. Chinn (2004). A decomposition of global linkages in financial markets over time. Review of Economics and Statistics, 86, 705-722.

Frankel, J. A., and A. K. Rose (1996). Currency crashes in emerging markets: An empirical treatment. Journal of International Economics, 41, 351-366.

Fratzscher, M., (2009). What explains global exchange rate movements during the financial crisis? European Central Bank Working Paper no. 1060.

Fry, M., D. Julius, L. Mahadeva, S. Roger and G. Sterne (2000). 'Key issues in the choice of monetary policy frameworks'. In Monetary Policy Frameworks in a Global Context, L. Mahadeva and G. Sterne (eds.). Bank of England. London: Routledge.

Hoelscher, D. S. and M. Quintyn (2003). Managing systemic banking crises. IMF Occasional Paper, no. 224.

Hoggarth, G., R. Reis, and V. Saporta (2002). Costs of banking system instability: Some empirical evidence. Journal of Banking and Finance, 26, 825-855.

International Monetary Fund (1998). Financial crisis: Characteristics and Indicators of Vulnerability. World Economic Outlook (Chapter 4), 74-81.

Kose, A., E. Prasad and M. Terrones (2009). Does openness to international financial flows raise productivity growth? Journal of International Money and Finance, 28, 554-580.

Kuttner, K. N., and A. S. Posen (2000). Inflation, monetary transparency, and G3 exchange rate volatility. Institute for International Economics Working Paper, no. 00-6.

Laeven, L., and F. Valencia (2008). Systemic banking crises: A new database. IMF Working Paper, WP/08/224.

Lane, P. R., and G. M. Milesi-Ferretti (2006). The external wealth of nations Mark II: Revised and extended estimates of foreign assets and liabilities, 1970-2004. IMF Working Paper, WP/06/69.

Lane, P. R., and G. M. Milesi-Ferretti (2010). The cross-country incidence of the global crisis. Unpublished manuscript.

Levchenko, A. A., L. Lewis and L. L. Tesar (2009). The collapse of international trade during the 2008-2009 crisis: In search for a smoking gun. Prepared for the IMF Economic Review special issue: Economic Linkages, Spillovers and the Financial Crisis.

McGuire, P., and G. von Peter (2009). The US dollar shortage in global banking and the international policy response. BIS Working Papers, no. 291.

Obstfeld, M., J. C. Shambaugh and A. M. Taylor (2009). Financial instability, reserves and central bank swap lines in the panic of 2008. American Economic Review, 99, 480486.

Pétursson, T. G., (2010). Inflation control around the world. Why are some countries more successful than others? In Inflation Targeting Twenty Years On: Past Lessons and Future Prospects, D. Cobham, Ø. Eitrheim, S. Gerlach and J. F. Qvigstad (eds.). Cambridge: Cambridge University Press.

Reinhart, C. M., and K. S. Rogoff (2009). This Time Its Different: Eight Centuries of Financial Folly. Princeton: Princeton University Press. 
Rose, A. K., and M. M. Spiegel (2009a). Cross-country causes and consequences of the 2008 crisis: Early warning. Federal Reserve Bank of San Francisco Working Paper 200917.

Rose, A. K., and M. M. Spiegel (2009b). Cross-country causes and consequences of the 2008 crisis: International linkages and American exposure. NBER Working Paper Series, no. 15358.

The Banker (2008). Top 1000 World Banks. London: The Financial Times Limited, July 2008.

Tong, H., and S. Wei (2009). The composition matters: Capital inflows and liquidity crunch during a global economic crisis. IMF Working Paper, WP/09/164. 


\section{Economics Working Paper}

2010-4: $\quad$ Torben M. Andersen and Allan Sørensen: Product market integration, rents and wage inequality

2010-5: John Kennes and Daniel le Maire: Coordination Frictions and Job Heterogeneity: A Discrete Time Analysis

2010-6: $\quad$ Philipp J.H. Schröder and Allan Sørensen: The Theoretical Equivalent of Empirically Measurable Exporter Productivity when Firms are Heterogeneous

2010-7: Nabanita Datta Gupta and Marianne Simonsen: Effects of Universal Child Care Participation on Pre-teen Skills and Risky Behaviors

2010-8: $\quad$ Olaf Posch and Timo Trimborn: Numerical solution of continuous-time DSGE models under Poisson uncertainty

2010-9: Torben M. Andersen and Allan Sørensen: Globalization, tax distortions and public sector retrenchment

2010-10: $\quad$ Philipp J.H. Schröder and Allan Sørensen: Ad valorem versus unit taxes: Monopolistic competition, heterogeneous firms, and intra-industry reallocations

2010-11: Søren Leth-Petersen and Niels Skipper: Income and the use of prescription drugs for near retirement individuals

2010-12: $\quad$ Niels Skipper: On Utilization and Stockpiling of Prescription Drugs when Copayments Increase: Heterogeneity across Types of Drugs

2010-13: Kenneth L. Sørensen and Rune M. Vejlin: Worker and Firm Heterogeneity in Wage Growth: An AKM approach

2010-14: $\quad$ Rune Vejlin: Residential Location, Job Location, and Wages: Theory and Empirics

2010-15: Paola Andrea Barrientos Quiroga: Convergence Patterns in Latin America

2010-16: Torben M. Andersen and Michael Svarer: Business Cycle Dependent Unemployment Insurance

2010-17: Thorvardur Tjörvi Ólafsson and Thórarinn G. Pétursson: Weathering the financial storm: The importance of fundamentals and flexibility 